\title{
A new frog from the Leptodactylus fuscus species group (Anura: Leptodactylidae), endemic from the South American Gran Chaco
}

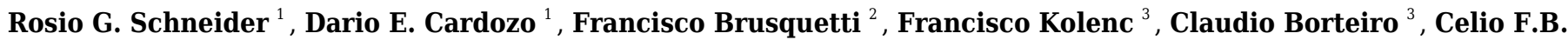
Haddad $^{4}$, Nestor G. Basso ${ }^{5}$, Diego Baldo ${ }^{\text {Corresp. } 1}$

${ }^{1}$ Laboratorio de Genética Evolutiva, Instituto de Biología Subtropical (CONICET-UNaM), Facultad de Ciencias Exactas Químicas y Naturales, Universidad Nacional de Misiones, Posadas, Misiones, Argentina

2 Instituto de Investigación Biológica del Paraguay, Asunción, Paraguay

3 Sección Herpetología, Museo Nacional de Historia Natural, Montevideo, Uruguay

4 Departamento de Zoología, Instituto de Biociências e Centro de Aquicultura (CAUNESP). Universidade Estadual Paulista (UNESP), Río Claro, São Paulo, Brazil

5 Instituto de Diversidad y Evolución Austral (IDEAUS-CONICET), Puerto Madryn, Chubut, Argentina

Corresponding Author: Diego Baldo

Email address: diegobaldo@gmail.com

A new species of Leptodactylus frog (Anura: Leptodactylidae) from the South American Gran Chaco, morphologically similar and previously confused with the widespread $L$. mystacinus, is described, through the use of multiple sources of evidence (molecular, external morphology, coloration, osteology, bioacoustics, and behavior). The phylogenetic analysis with partial sequences of mitochondrial rDNA genes ( $12 \mathrm{~S}$ and $16 \mathrm{~S}$ ) recovered the new species within the $L$. fuscus group, but being highly divergent ( $>3 \%$ genetic distance in 16S). The new species was recovered as sister taxa of L. mystacinus, from which it is distinguished by tympanum coloration, cephalic index, dorsum and legs coloration, and some osteological differences in nasals and prevomers. This new frog is characterized by a moderate body size (SVL 46.80-66.21 mm), distinctive color pattern (reddish dorsal surfaces of body with noticeable black stripes in the dorsolateral folds), a circular and dark tympanum with dark tympanic annuli, and behavior of males that call on top of fallen logs and tree branches close to the ground. 
1 A new frog from the Leptodactylus fuscus species group (Anura: Leptodactylidae), endemic

2

3

4 New Leptodactylus frog

5

6 Rosio G. Schneider ${ }^{1}$, Darío E. Cardozo ${ }^{1}$, Francisco Brusquetti ${ }^{2}$, Francisco Kolenc ${ }^{3}$, Claudio

7 Borteiro $^{3}$, Celio F. B. Haddad ${ }^{4}$, Néstor G. Basso 5 \& Diego Baldo ${ }^{*}$

8

9 1'Laboratorio de Genética Evolutiva, Instituto de Biología Subtropical (CONICET-UNaM),

10

Facultad de Ciencias Exactas Químicas y Naturales, Universidad Nacional de Misiones; Posadas,

11 Argentina.

12 2Instituto de Investigación Biológica del Paraguay; Asunción, Paraguay.

$13{ }^{3}$ Sección Herpetología, Museo Nacional de Historia Natural; Montevideo, Uruguay.

$14{ }^{4}$ Departamento de Zoología, Instituto de Biociências e Centro de Aquicultura (CAUNESP).

15 Universidade Estadual Paulista (UNESP); Rio Claro, SP, Brazil.

$16{ }^{5}$ Instituto de Diversidad y Evolución Austral (IDEAUS-CONICET); Puerto Madryn, Chubut, 17 Argentina

18

$19 *$ Corresponding author: Diego Baldo

20 E-mail: diegobaldo@gmail.com

22 


\section{Abstract}

24 A new species of Leptodactylus frog (Anura: Leptodactylidae) from the South American Gran

25 Chaco, morphologically similar and previously confused with the widespread L. mystacinus, is

26 described, through the use of multiple sources of evidence (molecular, external morphology,

27 coloration, osteology, bioacoustics, and behavior). The phylogenetic analysis with partial

28 sequences of mitochondrial rDNA genes (12S and 16S) recovered the new species within the $L$.

29 fuscus group, but being highly divergent ( $>3 \%$ genetic distance in 16S). The new species was

30 recovered as sister taxa of L. mystacinus, from which it is distinguished by tympanum coloration,

31 cephalic index, dorsum and legs coloration, and some osteological differences in nasals and

32 prevomers. This new frog is characterized by a moderate body size (SVL 46.80-66.21 mm),

33 distinctive color pattern (reddish dorsal surfaces of body with noticeable black stripes in the

34 dorsolateral folds), a circular and dark tympanum with dark tympanic annuli, and behavior of

35 males that call on top of fallen logs and tree branches close to the ground.

\section{Introduction}

38 The South American Gran Chaco ecoregion includes portions of northern and central Argentina,

39 southeastern Bolivia, western of Paraguay, and a small area in southwestern Brazil. Temperature

40 and rainfall in this region contribute to an increasing gradient of aridity from East to West, which

41 have led to a distinction between Humid and Dry Chaco subregions (Dinerstein et al., 1995;

42 Olson et al., 2001). The Dry Chaco occupies an area of nearly $225,500 \mathrm{~km}^{2}$, extending over a

43 large part of the northwestern portion of the ecoregion, being to date the largest most preserved 
44 forest/savanna biome in South America, characterized by deciduous forests and arid-semiarid 45 climate with less than $900 \mathrm{~mm}$ of annual rainfall (Grau et al., 2015).

46 This ecoregion presents a high richness of anurans, with frogs of the genus Leptodactylus

47 being one of its most widespread and abundant components (Köhler et al., 2000; Brusquetti \&

48 Lavilla, 2006; Álvarez et al., 2009). This genus comprises 74 species, occurring from southern

49 North America to central South America, including the West Indies (Frost, 2019). Heyer

50 (1969a), based on morphology and behavioral characters, assigned Leptodactylus species to five

51 phenetic groups: L. fuscus, L. marmoratus, L. melanonotus, L. ocellatus (= L. latrans), and L.

52 pentadactylus. The L. marmoratus group was later transferred by this same author to Adenomera

53 (Heyer, 1974), and the remaining four species groups have suffered numerous taxonomic

54 rearrangements (e.g. Heyer, 1969a, b, 1970, 1973, 1974, 1978, 1979; Maxson \& Heyer, 1988;

55 Frost et al., 2006; Ponssa, 2008; de Sá et al., 2014).

56 The monophyly of the Leptodactyus fuscus species group was first tested by Ponssa (2008)

57 based on morphological characters. More recently, de Sá et al. (2014) provided the first

58 phylogenetic hypothesis for the genus Leptodactylus using two different approaches: a) a

59 molecular matrix (partial sequences of mitochondrial 12S and 16S ribosomal DNA genes, and

60 the nuclear gene Rhodopsin), and b) these molecular data combined with the morphological

61 character matrix of Ponssa (2008). These authors recovered Leptodactylus as monophyletic in

62 the total evidence analyses, but molecular data alone did not support its monophyly (de Sá et al., 63 2014).

64 The Leptodactylus fuscus species group is the most diverse and widely distributed of the 65 genus, with 30 currently recognized species (de Sá et al., 2014) adapted to terrestrial life. Its 66 members have similar external morphology and share some particular reproductive features like 
67 oviposition in foam nests that are sheltered in underground chambers, and partial independence

68 of tadpoles from the aquatic environment (Heyer, 1969b, 1978).

69 Leptodactylus mystacinus is a widely distributed species of the L. fuscus group that is

70 present in varied environments east of the Andes, in the Yungas of Bolivia and northwestern

71 Argentina, extending eastwards to Paraguay, central and southern Brazil, and more southwards

72 to the Pampas region in central Argentina and Uruguay (Heyer et al., 2003; de Carvalho et al.,

73 2008). Several works have indicated the existence of some relevant variation among populations

74 of this species along its distribution, concerning morphology and coloration patterns of larvae

75 and adults (Cei, 1980; Heyer et al., 2003; Langone \& de Sá, 2005), chromosomal polymorphisms

76 (Bogart, 1974; Amaro-Ghilardi et al., 2006; Silva et al., 2006), and genetic divergence for

77 Bolivian lineages (Jansen et al., 2011). This variation has led to the proposal of some authors that

78 L. mystacinus represents a species complex (Heyer et al., 2003; Jansen et al., 2011, 2016), which

79 was yet not thoroughly tested.

80 In the present work we reviewed specimens of Leptodactylus mystacinus throughout its

81 geographic distribution and found that the specimens from the South American Gran Chaco

82 belong to a different species that is described herein. This new species was distinguished from $L$.

83 mystacinus based on the use of multiple sources of evidence of external adult morphology,

84 coloration, osteology, behavior, and genetic distances. In addition, we performed a phylogenetic

85 analysis under Maximum Parsimony and Bayesian approach in order to test their phylogenetic

86 position.

87

\section{Materials and methods}

\section{Molecular procedures}


90 We obtained new sequences for 23 specimens previously assigned to Leptodactylus mystacinus,

91 L. cupreus, and L. bufonius, 20 of which were collected by us, and three obtained from biological

92 collections. Other sequences used in this work, mainly outgroups, come from GenBank

93 (Appendix I).

94 Total genomic DNA was extracted from ethanol-preserved tissues (muscle/liver) using a

95 saline method (Aljanabi \& Martinez, 1997). Partial sequences of 12S and 16S ribosomal DNA

96 genes were obtained via the Polymerase Chain Reaction (PCR): a segment of about 800 base

97 pairs (bp) from the 12S rDNA gene was amplified using the primers 12Sa, 12Sb, 12STphef and

98 12SRdS (Kocher et al., 1989; Wiens et al., 2005); while a segment of about 900 bp from the 16S

99 rDNA gene was amplified with primers 16sL2A, 16sH10, 16SAr and 16SBr (Palumbi et al.,

100 1991; Hedges, 1994). The PCR protocol consisted of an initial denaturation step at $95^{\circ} \mathrm{C}(10$

$101 \mathrm{~min}), 35$ cycles consisting of $95^{\circ} \mathrm{C}(30 \mathrm{~s})$ for denaturation, $55^{\circ} \mathrm{C}(1 \mathrm{~min})$ for annealing, and $72^{\circ} \mathrm{C}$

102 (2 min) for extension; and a final extension step at $72^{\circ} \mathrm{C}(10 \mathrm{~min})$. PCR-amplified products were

103 purified with an Accuprep purification Kit (Bioneer) and sequenced in both directions in

104 automatic sequencers ABI 3730XL (Macrogen, South Korea). Chromatograms obtained from the

105 automated sequencer were processed using Sequencher v4.5 (Gene Codes, Ann Arbor, MI,

106 USA), and complete sequences were edited with BioEdit v7.0.5.3 (Hall, 1999) and deposited in

107 GenBank (Appendix I).

108

109 Phylogenetic analyses and genetic distances

110 In order to test the distinctiveness and phylogenetic position of the new species, we obtained

111 DNA sequences of two mitochondrial genes (12S-16S » $1641 \mathrm{bp}$ ) from several individuals and

112 localities of this taxon, also of Leptodactylus mystacinus and two additional species of the $L$. 
113 fuscus group to complete the sampling: L. cupreus and L. bufonius (Appendix I). The

114 phylogenetic analyses included sequences of all species in the L. fuscus group provided by de Sá

115 et al. (2014) available from GenBank (Appendix I). We excluded the 16S sequence of L. fragilis

116 employed by these authors (KM091585) because their identity is doubtful (BLAST searches

117 resulted in $92 \%$ identity with sequences of Smilisca baudinii). We used only the available $12 \mathrm{~S}$

118 fragment of L. fragilis (KM091469). Additional doubtful or missing sequences were excluded of 119 the analyses, or exchanged for others available in GenBank (see details in Appendix I).

120 We used as outgroup sequences of all species groups within Leptodactylus: L. bolivianus, L. 121 latrans, L. macrosternum, L. chaquensis (L. latrans group); L. natalensis, L. podicipinus (L.

122

123

124

125

126

127

128

129

130

131

132 133 melanonotus group); L. rugosus, L. rhodomystax, L. pentadactylus, L. myersi (L. pentadactylus group); and we also included Hydrolaetare caparu, Physalaemus cuvieri, Engystomops petersi, and Hyalinobatrachium fleishmanni to root the trees (Appendix I).

Sequences were aligned using MAFFT v6.240 (Katoh \& Toh, 2008) under the strategy GINS-i and default parameters for gaps opening and extension gaps. The isolated fragments were concatenated using Sequence Matrix v1.8 (Vaidya et al., 2011). Phylogenetic analyses were performed with 1641 characters, including 68 terminals.

The phylogenetic analyses were performed under Maximum Parsimony and Bayesian approach. The first was done with TNT v1.1 (Goloboff et al., 2008), using gaps as missing data, and New Technology search with 1000 random addition sequences. The branch supports were tested with 1000 pseudo-replicates obtaining absolute frequencies of Bootstrap and Jackknifing, the latter with removal probability of $36 \%$ (Farris et al., 1996).

To construct trees under Bayesian approach we firstly used PartitionFinder v1.1.0 (Lanfear et al., 2012) to infer the best partition scheme and the evolutionary model that best fitted each

Peer] reviewing PDF | (2019:07:39018:1:2:CHECK 6 Sep 2019) 
136 partition. We analized $12 \mathrm{~S}$ and $16 \mathrm{~S}$ genes separately and selected models under the Akaike

137 information criterion (Akaike, 1973) using the "greedy" heuristic search algorithm and linked

138 branch lengths. The best model of evolution for both genes was GTR (General time reversible) +

139 I (proportion of invariable sites) $+\mathrm{G}$ (gamma distribution). We performed the analysis in

140 MrBayes v3.2.6 (Ronquist \& Huelsenbeck, 2003) on XSEDE in CIPRES Science Gateway

141 Webserver (Miller et al., 2010), implementing the inferred model of nucleotide substitution on

142 two independent runs, each one with four chains sampling every 10,000 generations, for 100

143 million generations and discarding the first 25,000 trees as burn-in. We verified convergence

144 with TRACER v1.5 (Rambaut \& Drummond, 2007) and by examining the standard deviation of

145 split frequencies between independent runs $(<0.01)$.

146 For the estimation of sequence divergences within the Leptodactylus fuscus group, including

147 Leptodactylus sp. nov. (Appendix I), uncorrected pairwise distances (p-distances) of a partial

148 fragment of the mitochondrial 16S rDNA gene were calculated in PAUP* v4.0b10 (Swofford,

149 2000). The sequences were aligned using MAFFT, under the strategy G-INS-i with default

150 parameters for gaps opening and extension, obtaining a matrix of $478 \mathrm{bp}$.

151

152 External morphology and osteology

153 Analyzed material, types, and referred specimens, are stored at LGE, IIBP-H, MACN and

154 CENAI List of specimens in Appendix II. Institutional abbreviations follow Sabaj (2016).

155 Specimen collections were made in each country with the following authorizations numbers:

156 Argentina (MEyRNR 007/2009; 048/2013; 072/2014; 061/2015; 073/2016; 035/2017; DPB

157 171/2015), Brazil (SISBIO 57098-1), Paraguay (MADES 186/2016, 232/2017, 196/2018); and

158 Uruguay (MGAyP 199/13, 137/16). 
Fourteen morphological measurements were taken from 43 adult specimens of the new

160

161

162

163

164

165

166

167

168

169

170

171

172

173

174

175

\section{Advertisement calls}

177 We analyzed 241 advertisement calls of five males (IIBP-H 728, LGE 8085, and three 178

taxon (37 males, 6 females): snout-vent length (SVL), head length (HL), head width (HW), eye diameter (ED), tympanum diameter (TYD), eye-nostril distance (END), interorbital distance (IOD), internarial distance (IND), forearm length (FAL), hand length (HDL), thigh length (THL), tibia length (TL), tarsus length (TSL), and foot length (FL), following Duellman (1970) and Heyer et al. (1990). Measurements were recorded with a Mitutoyo digital caliper (0.01 mm). Sex was determined by visual inspection of male secondary sexual characters and presence of ovarian follicles in females. For comparison, 734 specimens of Leptodactylus mystacinus (584 males, 150 females) were measured.

Osteological descriptions are based on nine adult males (LGE 8085, 15214, 15241, FML $3661,12315,12343,12345-7)$, previously cleared and stained using the technique of Taylor \& Van Dyke (1985). We followed the terminology of Lynch (1971), Trueb (1973), Emerson (1982), and Ponssa (2008) for general features; Trewavas (1933) for the hyoid and larynx; Alberch \& Gale (1985) for the phalangeal formula; and Fabrezi $(1992,1993)$ and Fabrezi \& Alberch (1996) for the carpus and tarsus. For comparison purposes, we cleared and stained three adult males of Leptodactylus mystacinus (LGE 14998, 15207, 15233).

\section{We analyzed 241 advertisement calls of five males (IIBP-H 728, LGE 8085, and three}

unvouchered specimens) of the new species and 390 advertisement calls obtained from 13 males of Leptodactylus mystacinus (LGE 15209-10, and 11 unvouchered specimens). Advertisement calls were recorded with a Sony WMD6C recorder, and a Sennheiser ME66/K6 directional microphone. The recordings are deposited in the sound collection of the LGE. In addition, we 
182 analyzed 850 advertisement calls of 41 males of L. mystacinus provided by Fonoteca Neotropical 183 Jacques Vielliard (UNICAMP), Fonoteca Zoológica of the Museo Nacional de Ciencias

184 Naturales (Madrid), and EcoRegistros (Argentina) (details in Appendix III). All recordings were 185 analyzed employing Sound Forge Pro v11.0 (Magix GmbH \& Co) with an FFT of 512 points, at 186 a sampling rate of 44.1 kiloHertz and 16-bit precision. The following traits were measured: call

187 duration (miliseconds, ms), intercall interval (ms), call rate (calls/second), and dominant 188 frequency (hertz, Hz), following Heyer et al. (1990).

190 Nomenclatural acts

191 The electronic version of this article in Portable Document Format (PDF) will represent a 192 published work according to the International Commission on Zoological Nomenclature (ICZN), 193 and hence the new names contained in the electronic version are effectively published under that 194 Code from the electronic edition alone. This published work and the nomenclatural acts it contains 195 have been registered in ZooBank, the online registration system for the ICZN. The ZooBank 196 LSIDs (Life Science Identifiers) can be resolved and the associated information viewed through 197 any standard web browser by appending the LSID to the prefix http://zoobank.org/. The LSID for 198 this publication is: urn:1sid:zoobank.org:pub:7AE8062D-2F27-4F99-AC5E-8D2A94874EF3. The 199 online version of this work is archived and available from the following digital repositories: PeerJ, 200 PubMed Central and CLOCKSS.

201

202 Results

203 Molecular phylogenetic analysis 
204 The Maximum Parsimony (MP) analysis resulted in four most-parsimonious trees of 3312 steps 205 (Fig. 1a). The Leptodactylus fuscus group was recovered as sister of a clade formed by the $L$. 206 melanonotus + L. latrans groups, but poorly supported. Within the L. fuscus group, two large 207 and poorly supported clades were recovered; one that includes L. ventrimaculatus, L. labrosus, L. 208 laticeps, and L. syphax, and other that includes the remaining species of the group. The same 209 relationships were recovered in the Bayesian approach (Appendix IV).

210 Specimens belonging to the Leptodactylus mystacinus species complex were recovered

211 nested in a clade along with L. cupreus, L. troglodytes, and L. bufonius, but forming two 212 independent lineages, strongly supported (Fig. 1b): lineage I) specimens from the Dry Chaco and 213 surroundings areas, and lineage II) specimens from the rest of the distribution currently known

214 for L. mystacinus. Both lineages have an allopatric geographic distribution and correspond to the 215 two species distinguished in addition by morphology and coloration.

216 The Bayesian approach showed some subtle differences in topology with respect to the MP 217 analysis (Appendix IV), but in both analyses Leptodactylus and the L. fuscus group were

218 recovered as monophyletic. Howerver, this relationships of the L. fuscus group and the other 219 species groups remain unresolved with this approach. The relationships within the clade 220 containing the new species were consistent with those recovered under MP.

221 The new species showed significant genetic divergences (p-distances) in the 16S rDNA 222 sequences, which ranged 3-4.4\% with the closely related L. mystacinus, and 5.7-12.5\% with 223 the remaining species of the Leptodactylus fuscus group (Appendix V). Furthermore, the new 224 species showed an intra-specific variability up to $1.3 \%$.

225

\section{Assignation of available names}


227 Leptodactylus mystacinus (Burmeister, 1861). Type locality: "Rozario" (= Rosario, Santa Fé

228 Province, Argentina). Type MLU unnumbered, according to Heyer (1978). We examined the

229 type specimen through high quality color photographs (Appendix VI). Although we did not have

230 topotypic specimens to include in our analysis, we examined specimens from nearby localities

231 (Los Nogales and Las Rosas; Santa Fé Province; $86 \mathrm{~km}$ and $95 \mathrm{~km}$ respectively from Rosario).

232 Their morphology and the location of Rosario, deeply nested within the geographic distribution

233 of lineage II of our phylogenetic analysis, allowed us to assign the name Leptodactylus

234 mystacinus to this widespread lineage.

235

236

Cystignathus labialis Cope, 1877. Type locality: unknown, "the precise habitat of this species is

237 at present uncertain. It is probably a part of Sumichrast's Mexican collection” (Cope, 1877).

238 Type series USNM 31300-5, according to Kellogg (1932). Specimen USNM 31302 considered

239 holotype by Cochran (1961), which is actually a lectotype designation, according to Frost (2019).

240 Heyer (1978) studied in detail the type series and considered them conspecific with

241 Leptodactylus mystacinus based on their morphology, despite being very faded juvenile

242 specimens. Heyer (1978) also discussed the origin of these specimens, noticing that Cope (1877)

243 published in that same paper the study of a collection of amphibians and reptiles of origin

244 "unknown, but supposed to be the Argentine Confederation", and proposed that the type series of

245 C. labialis could have been part of this collection. High quality photos of four specimens of the

246 type series (USNM 31302, lectotype; and USNM 31303-5, paralectotypes; Appendix VII) of

247 Cystignathus labialis were analyzed by us. We agree with Heyer (1978) that based on their

248 morphology and Cope's original description, they closely resemble L. mystacinus sensu lato.

249 Based on the diagnostic characters identified by us (see below), we tried to assign these 
250 specimens to one of the two lineages recovered in our phylogenetic analysis. Since the

251 specimens are very faded and the diagnostic characters cannot be deduced from Cope's original

252 description, coloration pattern is not useful for this task. Fortunately, their morphometric indexes

253 (Cephalic index $=$ CI: head length/head width, and relation between tympanum and eye diameter

$254=\mathrm{TYD} / \mathrm{ED}$ ) could be calculated from the photographs, and they overlap with juveniles of $L$.

255 mystacinus, while significantly differ from juveniles of Leptodactylus sp. nov.: C. labialis: CI

$2560.98-1.01(0.99 \pm 0.01)$, TYD/ED 0.51-0.61 (0.57 \pm 0.04$) ;$ L. mystacinus: CI 0.95-1.08 $(1.01 \pm$

257 0.06), TYD/ED 0.49-0.67 (0.59 \pm 0.07$)$; Leptodactylus sp. nov.: $0.80-0.89(0.84 \pm 0.03), 0.43-$

$2580.48(0.45 \pm 0.024)$. Regarding this evidence, C. labialis still has to be considered a junior

259 synonym of L. mystacinus, leaving lineage I of our phylogenetic analysis without an available

260 name.

261

262 Species Description

263

Leptodactylus apepyta sp. nov.

264

urn:1sid:zoobank.org:act:BCA45181-9C6B-4275-A9E9-BA58D96DE5CE

265

(Figs. 2 and 3; Table 1)

266 Chresonymy in Appendix VIII.

267 Holotype. LGE 8114, adult male, from Argentina, Formosa province, Patiño Department, Las

268 Lomitas (2432'44.1'’S, 60³8'33.3'”'W, $142 \mathrm{~m}$ above sea level, asl), collected on January 29

2692014 by Baldo D., Boeris J.M., Brusquetti F., and J. Grosso (Figs. 2 and 3).

270 Paratopotypes. Four adult males: LGE 8085-7, 8113 (same data as holotype). 
271 Paratypes. Seventeen adult males: LGE 8181, 8384, 9399, 12290, 12298, 15227, 15236, 15241,

272 15250-1, 15268, 15272, 15274-6, 15280, 16944; three adult females: LGE 12095, 15240,

273 15279; and one juvenile: LGE 15232 (details in Appendix II).

274

275 Referred specimens. Seventeen adult males, five adult females, and nineteen juveniles (details 276 in Appendix II).

277

278 Etymology

279 The specific epithet is an indeclinable noun, constructed from the words of the Guaraní language 280 apé (= back of the neck, dorsum) and pytã (= red), in reference to the intense brick red dorsum of 281 adult and juvenile live specimens.

282

283 Definition and diagnosis

284 Leptodactylus apepyta sp. nov. is assigned to the Leptodactylus fuscus group (sensu Heyer 285 (1969b)) by its phylogenetic position, and by the presence of the following synaphomorphies 286 (Ponssa, 2008): 1) tectum nasi and alary process of premaxilla at the same level; 2) frontoparietal 287 with posterior margin convex, and 3) cultriform process of parasphenoid sited between 288 neopalatines.

289 The new species is diagnosed from the other species of the Leptodactylus fuscus group by 290 the following combination of character states: 1) moderate size sensu Heyer \& Thompson (2000) 291 (SVL 46.8-61.4 $\mathrm{mm}$ in males; 51.7-66.2 $\mathrm{mm}$ in females); 2) robust body aspect in dorsal view; 292 3) head wider than long (CI 0.77-0.95); 4) small, circular, and dark tympanum, with dark 293 tympanic annuli; 5) black broad stripe from tip of snout to the insertion of the forelimb; 6) a 
294 distinct light upper lip stripe; 7) one or two pairs of dorsolateral folds, with distinct uninterrupted 295 dark stripes coincident with the upper pair, and interrupted dark stripes in the dorsolateral folds 296 of the flanks; 8) reddish color on dorsal surfaces of body and limbs; 9) dorsum with small dark

297 spots; 10) thigh, tibia, and tarsus with broad, diffuse, and dark bars; and 11) advertisement call 298 composed by a single, short (30-68 ms), and non-pulsed note; call rate of 3.86-7.69 calls/s,

299

300

301

302

303

304 305

306

307

308

309

310

311

312

313

314

315 without harmonic structure and with dominant frequency between 2155 and $2457 \mathrm{~Hz}$; 12) males usually call on the top of fallen logs and low branches of trees.

\section{Comparisons with other species}

According to the available information, Leptodactylus apepyta sp. nov. can be distinguished from all other known species of the Leptodactylus fuscus group by a combination of external morphology, osteology, acoustics, behavior, and rDNA sequences (12S and 16S).

Leptodactylus apepyta $\mathbf{s p . ~ n o v . ~ i s ~ d i s t i n g u i s h e d ~ f r o m ~ L . ~ a l b i l a b r i s , ~ L . ~ l a t i n a s u s , ~} L$.

longirostris, L. marambaiae, L. caatingae, L. camaquara, L. cunicularius, L. furnarius, L. tapiti, L. elenae, L. fragilis, L. oreomantis, and L. plaumanni by the larger size (SVL 46.8-61.4 $\mathrm{mm}$ in males; 51.7-66.2 in females of L. apepyta sp. nov.; combined SVL 23-46.4 mm in males; 29.1$49.6 \mathrm{~mm}$ in females of the other species; Heyer, 1978; Sazima \& Bokermann, 1978; Heyer \& Heyer, 2002; Heyer \& Juncá, 2003; Heyer et al., 2006; de Carvalho et al., 2013; de Sá et al., 2014) and from L. laticeps by the smaller size $(94.2-109.7 \mathrm{~mm}$ in males; $88-117 \mathrm{~mm}$ in females; de Sá et al., 2014).

Leptodactylus apepyta $\mathbf{s p . ~ n o v . ~ c a n ~ a d d i t i o n a l l y ~ b e ~ d i s t i n g u i s h e d ~ f r o m ~} L$. camaquara, $L$. furnarius, L. jolyi, L. tapiti, L. fuscus, L. gracilis, L. longirostris, L. marambaiae, L. oreomantis, L. plaumanni, L. poecilochilus, and L. sertanejo by the absence of a longitudinal mid-dorsal light 
317 stripe, present in the other mentioned species (Heyer, 1970, 1978; Sazima \& Bokermann, 1978;

318 Giaretta \& Costa, 2007; de Carvalho et al., 2013, de Sá et al., 2014). The presence of one or two

319 pairs of dorsolateral folds in the new species differentiates it from L. bufonius, L. latinasus, L.

320 troglodytes, L. fragilis, L. laticeps, L. syphax, and L. cunicularis, with dorsolateral folds

321 undefined or absent (Heyer, 1978; Heyer et al., 2006, 2010; Sazima \& Bokermann, 1978; de Sá

322 et al., 2014). A light colored line on the dorsal surface of the tibia separate L. albilabris, $L$.

323 caatingae, L. cupreus and members of the L. mystaceus complex -L. elenae, L. mystaceus, L.

324 notoaktites, L. spixi, and L. didymus-(Heyer, 1978, 1983; Heyer \& Juncá, 2003; Heyer et al.,

325 1996; Caramaschi et al., 2008) from the new species, where this line is absent. The distinct light

326 upper lip stripe differentiates the new species from L. labrosus and L. ventrimaculatus, which

327 lack distinct stripe (Heyer, 1978).

328 Leptodactylus apepyta sp. nov. differs from the closely related L. mystacinus (character

329 states in parentheses) by: tympanum with dark annuli (light-colored annuli); head wider than

330 long, CI 0.77-0.95 (head longer than wide, CI 0.99-1.26); the dorsum generally with

331 pronounced reddish coloration with small dark spots (brown coloration); and legs with wide and

332 diffuse stripes (thin and defined stripes) (Heyer, 1978; Heyer et al., 2003). There are also some

333 subtle osteological differences between L. apepyta sp. nov. and L. mystacinus (Fig. 3 and

334 Appendix IX): the nasals in L. mystacinus are triangular with proportions equivalent in length

335 and width, while in L. apepyta sp. nov. they are wider, stretched, with slightly concave outer

336 edges. The lateral edges of the middle ramus of prevomers of L. apepyta sp. nov. are irregular,

337 more than in L. mystacinus in which they appear smooth giving it a triangular aspect.

338 The advertisement calls of Leptodactylus apepyta sp. nov. (Fig. 4A, B; Table 2) consist of a

339 single type of non-pulsed note and separates it from L. albilabris, L. caatingae, L. gracilis, L. 
340 jolyi, L. mystaceus, and L. sertanejo which produce pulsed calls (Heyer, 1978; Sazima \&

341 Bokermann, 1978; Heyer \& Juncá, 2003; Giaretta \& Costa, 2007), and from L. cunicularius, L.

342 oreomantis, and L. plaumanni, with trilled calls (Sazima \& Bokermann, 1978; Kwet et al., 2001;

343 de Carvalho et al., 2013). In comparison with the remaining species in the L. fuscus group that

344 also have calls with non-pulsed notes, the dominant frequency of the new taxon (2155 to 2457

$345 \mathrm{~Hz}$ ) is higher than those of $L$. bufonius, $L$. dydimus, $L$ elenae, $L$. fragilis, L. notoaktites, $L$.

346 poecilochilus, and L. spixi (combined dominant frequency range from 470-2033 Hz; Heyer,

347 1978; Heyer et al., 1996; Bilate et al., 2006); and lower than those of L. cupreus, L. furnarius, $L$.

348 latinasus, L. marambaiae, and L. tapiti (combined dominant frequency range from 2600-4000

349 Hz; Heyer, 1978; Sazima \& Bokermann, 1978; Caramashi et al., 2008; Brandão et al., 2013).

350 The call duration of Leptodactylus apepyta sp. nov. ranges from 30-68 ms, being shorter

351 than those of L. fuscus and L. camaquara (150-300 ms; Sazima \& Bokermann, 1978; Heyer \&

352 Reid, 2003). It can also be distinguished from L. longirostris by a faster call rate (5.92 vs. 1.4-

3532.0 calls/s, respectively; Crombie \& Heyer, 1983).

354 Leptodactylus apepyta sp. nov. and L. mystacinus cannot be distinguished from each other

355 by their advertisement call, both species have similar structure and overlapping measured

356 variables (Fig. 4; Table 2). The advertisement calls of L. mystacinus (Fig. 4C, D), consist of a

357 series of single non-pulsed notes, produced at a rate of 6.08 calls $/ \mathrm{s}$. Call duration ranges from

$35827-66 \mathrm{~ms}(43.62 \pm 0.7 \mathrm{~ms})$, and intercall interval ranges from $84-221 \mathrm{~ms}(124.6 \pm 2.31 \mathrm{~ms})$. The

359 advertisement call lacks amplitude and frequency modulation, and dominant frequency ranges

360 from $1960-2874 \mathrm{~Hz}(2368.88 \pm 195.05 \mathrm{~Hz})$.

361

\section{Description of the holotype}


363 Adult male. Robust body aspect, moderate size (SVL $52.3 \mathrm{~mm}$ ), head wider than long (CI 0.9),

364 head length $34 \%$ of SVL. Snout sub-elliptical in dorsal view, and protruding in lateral view.

365 Canthus rostralis indistinct, loreal region oblique. Nostril closer to tip of snout than to the eye.

366 Prominent eye located laterally. Upper lip with a distinct light stripe; black broad stripe from tip

367 of snout to the insertion of the forelimb, passing on the eye and tympanum. Tongue large and

368 free posteriorly, notched from behind. Vomerine and maxillary teeth present. Tympanum

369 evident, circular with dark annuli, largely separated from eye. Tympanum diameter smaller than

370 eye diameter (TYD/ED 0.7). Supratympanic fold developed, from the eye to the forelimb

371 insertion. Commissural gland present. Dorsum with small dark spots. Two pairs of dorsolateral

372 folds. The upper pair accompanied by wide uninterrupted dark stripes; and interrupted dark

373 stripes in the folds of the flanks. Flanks with small-medium dark spots. Skin rough, with small

374 white tubercles on dorsum and flanks. Belly spotted. Dark throats, vocal sacs evident. Cloacal

375 zone without tubercles, femoral zone with smooth texture. Arm robust, stained dorsally. Hand

376 with slender fingers, with rounded tips, without webs or fringes. Relative finger lengths IV $>$ II $=$

377 V > III. Subarticular tubercles rounded, outer metacarpal tubercle rounded, inner metacarpal

378 tubercle elongate. No thumb asperities or prepollex visible. Legs robust, tibia larger than thigh;

379 broad and diffuse bars in thigh, tibia, and tarsus. Toe tips rounded, without webs or fringes.

380 Relative toe lengths IV $>$ III $>$ V $>$ II $>$ I. Subarticular tubercles rounded, outer metatarsal

381 tubercle small and rounded, inner metatarsal tubercle large. Small white tubercles in the sole of

382 tarsus.

383 Measurements of the holotype (in mm): SVL 52.3; HL 17.6; HW 19.7; ED 5.7; TYD 4.0; END

384 4.5; IOD 3.6; IND 3.9; FAL 8.7; HDL 12.4; THL 20.9; TL 21.4; TSL 12.0; FL 21.1. 


\section{Coloration in life}

387 Dorsum uniformly reddish (Fig. 5A). A wide black stripe from the tip of snout to the 388 supratympanic fold. Black tympanic membrane, with black tympanic annulus. Near the upper 389 half of the eye brown, and black below. Upper and lower lips dark grey. Dorsum with small 390 black spots. Black stripes accompany the dorsolateral folds, spreading in the dorsum, from the 391 nearest of supratympanic fold to groin. Forelimb reddish above, with a black stripe on anterior 392 and posterior sides of arm and diffuse black stripes on forearm. Thigh reddish above, with wide, 393 incomplete and diffuse dark bars in thigh and tibia. Belly and ventral surfaces of forelimb and 394 leg clear cream with diffuse spots. Gular region dark. Cloacal zone with distinct white tubercles. 395

\section{Color in preservative}

397 The reddish coloration becomes gray. Black stripes that accompany dorsolateral fold, lateral 398 head stripe, arm, and leg maintained the dark coloration. The belly continued whitish and the 399 vocal region grayish. Tympanum kept its dark coloration, with dark tympanic membrane and 400 dark tympanic annul. Eyes become complete black.

401

402 Variation

403 The reddish coloration of the dorsum of Leptodactylus apepyta sp. nov. can be brightly red 404 (LGE 8087, 8181, 15274-5, 15280, 16944, IIBP-H 728-9, 1738), sometimes less marked (LGE $405122,8085-6,8113,8384,9399,11231-3,12095,12290,12298,15214,15227,15232,15236$, $40615238,15240-1,15248-51,15268,15272,15276,15279$, IIBP-H 2308, 2848-9) (Fig. 6). In $L$. 407 mystacinus, a vast variation in coloration patterns was observed; most specimens have different 408 shades of brown coloration (Fig. 7). The specimen LGE 7890 of L. mystacinus from Argentina, 
409 Misiones Province, Itacaruaré showed a reddish coloration, similar to that of L. apepyta sp. nov.,

410 but it was clearly identifiable as L. mystacinus according to other morphological characteristics,

411 e.g. tympanum coloration (Fig. 7, H). Some specimens have thinner and conspicuous stripes in

412 the legs (LGE 8113, 16944), while others have diffuse or absent stripes (LGE 8086, LGE 8387,

$41312290,15263)$. The folds on the flanks are incomplete or absent. Specimen LGE 15251 has an

414 oblique stripe that goes through the dorsum. The specimens LGE 8384 and 15250 have the

415 posterior portion of the tympanic annuli less pigmented. Females are larger than males (SVL

416 females $59.2 \pm 5.6$ in $\mathrm{N}=6$; males $53.7 \pm 5.1, \mathrm{~N}=43$ ), and the males have brownish or blackish

417 vocal sacs. Specimen LGE 15232 has a malformation consisting of a duplication of the last

418 phalange of the fourth toe.

419

420 Osteology

421 Skull wider than long (Fig. 3A and B). Sphenethmoid with lateral margins straight. Prootics and

422 exoccipitals fused, with protuberant crest noticeable, condyles widely separated. Frontoparietals

423 rectangular that do not reach nasals. Anterior borders irregular, lateral borders parallel, posterior

424 margin convex, overlapping the prootics. Nasals expanded and subtriangular, in contact along

425 their entire length, not overlapping the maxillary. Laterals border irregular and curved. Nasal

426 capsule separated by the nasal cartilage. Parasphenoid t-shaped, cultriform process serrated

427 anteriorly, between neopalatines. Neopalatines posteriorly concave, overlap sphenethmoid in

428 their inner portion, and contact maxilla in the outer edge. Prevomers in broad median contact and

429 articulate the maxilla anteriorly. Middle ramus of prevomers bifid and rectangular, dentigerous

430 process curved with 13-17 teeth each. Complete maxillary arch. Premaxillas not fused, with 8-

43110 conical, curved and bicuspid teeth each. Alary process subrectangular. Pars palatina 
432 subrectangular, palatine process bifid. Maxillas bearing 47-51 teeth each, anterior tip sharp and

433 overlaps the premaxilla, posterior end articulates with quadratojugal. Quadratojugals well

434 developed, contacting maxilla. Mentomeckelian L-shaped. Dentary curved anteriorly. Angular

435 with anterior end sharp and articular region mineralized. Pterygoids in contact with parasphenoid

436 and articulate with the maxilla, anterior ramus expanded anteriorly; medial ramus reaches the

437 prootic and posterior ramus laminar and curved. Squamosals with zygomatic ramus subtriangular

438 and curved, otic ramus subtriangular and descendent ramus with canal in their middle extension.

439 Hyoid plate wide and cartilaginous (Fig. 3C). Hyale processes thin and curved. Alary process

440 thin, perpendicular to the hyoid plate. Posterolateral processes thin and mineralized.

441 Posteromedial processes mineralized, with posterior ends cartilaginous. Larynx with triangular

442 arytenoids and thinner cricoids as a circular ring. Vertebral column composed of eight

443 procoelous, imbricate, presacral vertebrae (Fig. 3D). Atlas not fused to the first vertebra, with

444 centrum wider than other vertebrae in ventral view. Cervical cotyles widely separated (type I of

445 Lynch, 1971); semilunar lateral and anteriorly oriented. Intercotylar region concave. Relative

446 lengths of transverse processes III $>$ IV $>$ V $=$ VI $=$ VII $=$ VIII $>$ II. Parasagittal processes

447 slightly curved, neural arch thin and sharp. Relative lengths of vertebral centra $2<3<4=$ rest of

448 vertebrae. Sacrum with modified transverse processes, sacral diapophyses oriented toward the

449 back, wider than presacral vertebrae. Ilio-sacral articulation short, narrow internal ligament joins

450 on the distal part of sacral diapophysis (type IIB of Emerson, 1982). Sesamoid of the sacral

451 diapophyses present. Sacral-coccygeal articulation bicondylar. Urostyle cylindrical, wide in the

452 anterior portion, thinner towards its posterior end, with notorious dorsal crest.

453 Pectoral girdle arciferal (Fig. 3E). Episternum cartilaginous and stick shaped.

454 Omosternum cartilaginous, distal end expanded. Xiphisternum expanded, mineralized anteriorly, 
455 the proportions between width and length vary according to the individual. Mesosternum

456 ossified, with medium line and anterior edge cartilaginous. Epicoracoid cartilages broadly

457 overlapped (right over the left). Clavicles curved and separated. Scapulas rectangular shaped and

458 wider than clavicles, with pars acromialis larger than pars glenoidalis. Coracoids subrectangular,

459 with distally expanded end, wider than clavicles. Cleithrum mineralized. Supraescapulas

460 cartilaginous and mineralized, rectangular shaped and wide in the distal part, with variation in

461 size according to the individual. Humerus slightly curved. Caput humeri rounded. Eminentia

462 capitata expanded and rather flattened. Humeral crista notorious. Radius-ulna fused. Carpal

463 morphology with ulnare, distal carpal 5-4-3, element Y, distal carpal 2, radial and proximal

464 element of prepollex (type E of Fabrezi, 1992; Fig. 3F). Phalangeal formula 2-2-3-3 and

465 relative length of digits IV $>$ II $=$ V > III. Fingertips knobbed. Glide and palmar sesamoids.

466 Prepollex with three segments. Nuptial spines absent. Pelvic girdle. Ilium with preacetabular area

467 projects anteriorly as a wedge, rounded border with well-defined curved edges and ilial shaft

468 stick shaped with well-developed dorsal crest. Ischium with postacetabular expansion triangular.

469 Pubis mineralized as a wedge between ilium and ischium. Femur slightly curved. Tibio-fibula

470 equal to femur in length, cartilage sesamoid present. Tarsus composed of element $\mathrm{Y}$, distal tarsal

4711 and distal tarsal 2-3 (Fig. 3G). Glide and plantar sesamoids present. Prehallux composed of

472 three segments. Phalangeal formula 2-2-3-4-3, toe tips knobbed.

473

474 Advertisement call and natural history notes

475 Leptodactylus apepyta sp. nov. is a species typical of forests and open areas on the Dry Chaco's

476 environments, characterized by scarce rainfalls and deciduous vegetation. Males were found

477 vocalizing after sunset during the rainy season, from mid-October to February. They usually 
478 begin to vocalize near to temporary ponds on the top of fallen logs and low branches of trees, up

479 to 1.5 meters high (Fig. 5B). The advertisement call consists of series of non-pulsed notes

480 emitted at a rate of 5.92 notes/s (Fig. 4A, B; Table 2). Note duration ranges from 30-68 ms (42.2

$481 \pm 0.82 \mathrm{~ms})$, and internote interval from 88-204 ms $(132.6 \pm 2.91 \mathrm{~ms})$. The call lacks amplitude

482 and frequency modulation. Dominant frequency = fundamental frequency, ranges from 2155-

$4832457 \mathrm{~Hz}$ (mean $2266 \pm 80.4 \mathrm{~Hz}$ ). Oviposition and tadpoles are unknown.

484

485 Geographic distribution

486 Leptodactylus apepyta sp. nov. occurs in the South American Gran Chaco in Argentina and

487 Paraguay (Fig. 8), almost exclusively inhabiting the Dry Chaco, with some scarce records in

488 surrounding areas of Humid Chaco (i.e. Pirané, Formosa province, Argentina; and Concepción,

489 Paraguay) and the Yungas ecoregion (i.e. Zapla, Jujuy province, Argentina). Additionally, a

490 GenBank sequence (JF789906, voucher not examined by us) of a specimen from the Chiquitanía 491 ecoregion (Ñuflo de Chávez province, Santa Cruz Department, Bolivia), was recovered as sister 492 of the all remaining terminals of L. apepyta sp. nov. in the phylogenetic analyses (Fig. 1B), and 493 due to its low genetic distance $(0,8-1 \%)$ we consider it conspecific with L. apepyta. Therefore, 494 the distribution range of L. apepyta sp. nov. would extend from middle Bolivia eastwards to the 495 Paraguay River in Paraguay (Presidente Hayes Department as eastern limits), and more 496 southwards reaches the northern half of Chaco and center of Santiago del Estero and southern 497 Tucumán provinces in Argentina.

498

499 Discussion 
500 Monophyly of Leptodactylus and the $L$. fuscus group, and comments on some

\section{1 internal relationships}

502 Although our molecular sampling was designed only to determine the phylogenetic position of

503 Leptodactylus apepyta sp. nov. and we did not include nuclear genes (i.e. rhodopsin), main

504 discrepancies with the previous hypotheses produced by the recent phylogeny of Leptodactylus

505 by de Sá et al. (2014) deserve some discussion. In the total evidence analysis of de Sá et al.

506 (2014) both the genus Leptodactylus and the L. fuscus group appear as monophyletic, but

507 paraphyletic in the molecular-only analysis. The analyses of de Sá et al. (2014) recovered $L$.

508 fragilis as sister taxon of the clade composed by L. melanonotus + Hydrolaterae + all remaining

509 Leptodactylus. Our dataset recovered Leptodactylus and the L. fuscus group as monophyletic but

510 low supported, with L. fragilis within a clade of this group that included L. longirostris $+L$.

511 poecilochilus. The non-monophyly of Leptodactylus obtained by de Sá et al. (2014) could be

512 attributed to the sequence of L. fragilis, apparently chimeric with a species of Hylini. Similar

513 discrepancies in topologies attributed to accidental chimeras or contaminated sequences were

514 detected, e.g., in Eupsophus (Blotto et al., 2013), Cycloramphidae (Fouquet et al., 2013),

515 Ceratophryidae (Faivovich et al., 2014)..

516 Leptodactylus mystacinus + L. apepyta sp. nov. were recovered by us in a clade formed

517 also by L. cupreus (not included in de Sá et al., 2014), L. troglodytes, and L. bufonius, in a

518 similar way to the total evidence results by de Sá et al. (2014) where L. ventrimaculatus $+L$.

519 labrosus are the sister taxa of all other species of the L. fuscus group; with L. bufonius, $L$.

520 troglodytes, and L. mystacinus forming a clade sister to the remaining species of the group.

521 However, the molecular-only analysis of de Sá et al. (2014) resulted in a very different topology

522 with L. bufonius, L. troglodytes, and L. mystacinus forming an early divergent grade within a 
523 clade with all species of L. mystaceus complex and some specimens of L. fuscus. In the

524 description of L. cupreus, it was assigned to the L. mystaceus complex based on morphological

525 and bioacustic characters (Caramaschi et al., 2008). However, Cassini et al. (2013) argued that

526 this relationship was only tentative and presented evidence suggesting that this species would be

527 more similar to L. mystacinus, which is congruent with our results.

528 The terminals of Leptodactylus fuscus 1-2 and 4-7 (we excluded sequences of $L$. fuscus

5293,8 , and 9 for low quality or missing data) formed a clade with relatively low genetic distances;

530 while in the analysis by de Sá et al. (2014) the terminals 6-9 were separately nested with $L$.

531 mystaceus. Camargo et al. (2006) affirmed that while their molecular data supports a multiple-

532 species hypothesis for L. fuscus, they did not find relevant differences in calls and morphology to

533 strongly clarify the taxonomic status of different lineages. Regarding L. mystaceus, we only used

534 sequences of two lineages ( 1 and 3 or $L$. cf. mystaceus), which were sister taxa, contrary to de Sá

535 et al. (2014) who found them as paraphyletic lineages. We do not rule out those discrepancies

536 with our results, it could be due to the inclusion of contaminated and low-quality sequences in

537 the analysis of de Sá et al. (2014).

538

539 Taxonomic conclusions

540 Phylogenetic topology, genetic p-distances, external morphology, coloration, osteology, and

541 behavior support the view that the nominal species Leptodactylus mystacinus is actually a

542 complex composed by two clearly distinct taxa: L. mystacinus, widely distributed and with

543 strong geographical and genetic structure, and L. apepyta sp. nov., endemic to the South

544 American Gran Chaco. The $3 \%$ genetic divergence found in the 16S rDNA between both

545 species is considered as "moderate" (Vences et al., 2005), but enough to identify candidate 
546 species among Neotropical anurans. The occurrence of cryptic species complexes is a frequent

547 phenomenon in anurans (e.g. Vences \& Wake, 2007; Castroviejo-Fisher et al., 2017). However,

548 this phenomenon has been poorly studied in the specious genus Leptodactylus, with only some

549 conflicts being reported in L. mystaceus (Heyer et al., 1996; de Sá et al., 2014), L. fuscus (Wynn

550 \& Heyer, 2001; Camargo et al., 2006), L. gracilis (Silva et al., 2004), and L. pentadactylus

551 (Gazoni et al., 2018), among others. The moderate levels of genetic divergence between $L$.

552 mystacinus and L. apepyta sp. nov., and its disjunct pattern ranges, could be explain that both

553 species have a great morphological similarity and identical advertisement calls. The

554 morphological characters we studied (i. e. general shape, head shape, tympanic annuli coloration,

555 general coloration, and striped patterns) allowed us to unequivocally distinguish Leptodactylus

556 apepyta sp. nov. from L. mystacinus. Although it was not possible to include sequences from the

557 type locality of L. mystacinus (Rosario, Santa Fé province, Argentina), external morphology of

558 the specimens analyzed from nearby locations (Las Rosas and Los Nogales, Santa Fé province),

559 and high quality photographs of the holotype of this species, allow easily to diagnose them as $L$.

560 mystacinus, and distinguish them from L. apepyta sp. nov.

561 In addition to external morphology, we found few osteological differences between the two

562 species in the shape of nasals and prevomers. Ponssa (2008) performed osteological studies on

563 some populations of Leptodactylus mystacinus from Argentina including specimens of $L$.

564 apepyta sp. nov., but this author did not report relevant differences among them. Furthermore, a

565 conservative osteological pattern can be depicted from the available osteological descriptions of

566 species in the L. fuscus group, with low variation among them (e.g. Heyer, 1998, Ponssa, 2006,

567 2008; Ponssa \& Barrionuevo, 2012). 
569 structure similar to previous descriptions (Barrio, 1965; Heyer et al. 2003; Oliveira Filho \&

570 Giaretta, 2008). We only found differences with the call duration reported by Barrio (1965), of

$571100 \mathrm{~ms}$; however, Heyer et al. (2003) suggested that the record of these high values could be due

572 to the methodology employed. The advertisement calls of L. apepyta sp. nov. are structurally

573 quite similar to the advertisement calls of L. mystacinus, as well as the quantitative parameters,

574 being indistinguishable. This phenomenon has already been observed in complexes of cryptic

575 species with allopatric distributions (e.g. Heyer \& Reid, 2003; Vences et al., 2008; Caminer et

576 al., 2017), while species with sympatric distributions tend to differentiate from each other,

577 according to the character displacement hypothesis (Brown \&Wilson, 1956), e.g. in Heyer et al.

578 (1996); Funk et al. (2011).

579 The natural history of the Leptodactylus apepyta sp. nov. is poorly known and virtually

580 nothing is known about its reproduction (e.g. amplexus, site and mode of oviposition, number of

581 eggs, and tadpoles). Noticeably, males show a unique behavior among Leptodactylids; they were

582 found vocalizing on the top of fallen logs and low branches of trees, up to 1.5 meters high (Fig.

583 5B). This behavior was never reported neither for its close relative L. mystacinus (Barrio, 1965;

584 Langone, 1995; Abrunhosa et al., 2001; Heyer et al., 2003; Oliveira Filho \& Giaretta, 2008) nor

585 for any other Leptodactylus species or genus in Leptodactylidae (Lynch 1971; Heyer 1978; de Sá

586 et al., 2014). Reproductive males of L. mystacinus vocalize at shelter under dead logs or rocks,

587 and males of most species in the L. fuscus group usually call from the ground, near or inside

588 underground chambers that they construct for reproduction (Heyer, 1978; de Sá et al., 2014).

589

590 Conservation status 
591 According to the criteria of the International Union for Conservation of Nature, Leptodactylus

592 apepyta sp. nov. should be considered in the category "Least concern". However, the known

593 distribution of L. apepyta sp. nov. corresponds to a new endemism for the Gran Chaco ecoregion

594 and eventually also to the Chiquitanía ecoregion, which is a transitional zone between the Chaco

595 and the Amazon with prevailing characteristics of Chaco environments (Ibisch et al., 2002). The

596 South American Gran Chaco is considered as of Conservation Priority 1 (Highest Priority at

597 Regional Scale; Dinerstein et al., 1995). Although it has been considered a region with low

598 diversity at the species level for some taxonomic groups (i.e. Short, 1975; López-González, 599 2004), it is inhabited by a large number of species of anurans, including two genera and more 600 than 20 endemic species (The Nature Conservancy, 2005; Nori et al., 2016). In addition, this 601 region represents the largest continuous dry forest remnant in South America, evidencing its 602 relevance for future conservation efforts (Maldonado \& Hohne, 2006; Gasparri \& Grau, 2009).

603

604 Acknowledgments

605 We thank to J. Faivovich and S. Nenda (MACN), S. Castroviejo-Fisher and G. Funk Pontes 606 (PUCRS), M. Borges Martins and D. Janisch Alvares (UFRGS), N. Pupin (CFBH), T. Grant 607 (MZUSP), S. Cechin (UFSM), M. T. Rodrigues (USP), J. Pombal Jr. and M. Woitovicz Cardoso 608 (MNRJ) and Diego Arrieta (MNHN) for providing access to specimens and assistance during the 609 visits and work in the respective herpetological collections; to the collectors of the studied 610 material; to E.R. Krauczuk, M. Sánchez and A.S. Du Port Bru for assistance with photographs;

611 to S. Cairo, R. Herrera, F. Marangoni, M.L. Ponssa, Fonoteca Neotropical Jacques Vielliard 612 (FNJV, UNICAMP), Fonoteca Zoológica of the Museo Nacional de Ciencias Naturales 
613 (FonoZoo, Madrid) and EcoRegistros (Argentina) for providing recordings of advertisement

614 calls.

615

\section{References}

617 Abrunhosa PA, Wogel H, Pombal Jr JP. 2001. Vocalização de quatro espécies de anuros do

618 Estado do Rio de Janeiro, Sudeste do Brasil (Amphibia, Hylidae, Leptodactylidae). Boletim do

619 Museu Nacional do Rio de Janeiro 472:1-12.

620 Akaike H. 1973. Information theory as an extension of the maximum likelihood principle. In:

621 Petrov BN, Csaki F, eds. Second international symposium on information theory. Budapest:

622 Akademiai Kiado, 267-281.

623 Alberch P, Gale EA. 1985. A developmental analysis of an evolutionary trend: digital reduction 624 in Amphibians. Evolution 39:8-23 DOI 10.1111/j.1558-5646.1985.tb04076.x.

625 Aljanabi SM, Martinez I. 1997. Universal and rapid salt-extraction of high quality genomic 626 DNA for PCR-based techniques. Nucleic Acids Research 25:4692-4693 DOI $627 \quad 10.1093 /$ nar/25.22.4692.

628 Álvarez BB, García JAR, Céspedez JA, Hernando AB, Zaracho VH, Calamante CC, Aguirre 629 RH. 2009. Herpetofauna, provinces of Chaco and Formosa, Chaco Oriental region, north-eastern 630 Argentina. Check List 5:74-82.

631 Amaro-Ghilardi RC, Skuk G, de Sá RO, Rodrigues MT, Yonenaga-Yassuda Y. 2006.

632 Karyotypes of eight species of Leptodactylus (Anura, Leptodactylidae) with a description of a 633 new karyotype for the genus. Phyllomedusa 5:119-133 DOI 10.11606/issn.2316-9079.v5i2p119634133. 
635 Barrio A. 1965. Afinidades del canto nupcial de las especies cavícolas del genero Leptodactylus 636 (Anura - Leptodactylidae). Physis 25:401-410.

637 Bilate M, Wogel H, Weber LN, Abrunhosa PA. 2006. Vocalizações e girino de Leptodactylus 638 spixi Heyer, 1983 (Amphibia, Anura, Leptodactylidae). Arquivos do Museu Nacional, Rio de 639 Janeiro 64:235-245.

640 Blotto BL, Nunez JJ, Basso NG, Úbeda CA, Wheeler WC, Faivovich J. 2013. Phylogenetic 641 relationships of a Patagonian frog radiation, the Alsodes + Eupsophus clade (Anura: Alsodidae), 642 with comments on the supposed paraphyly of Eupsophus. Cladistics 29:113-131 DOI 643 10.1111/j.1096-0031.2012.00417.x.

644 Bogart JP. 1974. A karyosystematic study of frogs in the genus Leptodactylus (Anura: 645 Leptodactylidae). Copeia 3:728-737 DOI 10.2307/1442686.

646 Brandão RA, Álvares R, Fajardo G, de Sá RO. 2013. The advertisement call of the poorly 647 known Leptodactylus tapiti (Anura, Leptodactylidae). Zootaxa 3616:284-286 DOI 648 10.11646/zootaxa.3616.3.6.

649 Brown WL, Wilson EO. 1956. Character displacement. Systematic zoology 5:49-64.

650 Brusquetti F, Lavilla EO. 2006. Lista comentada de los anfibios de Paraguay. Cuadernos de 651 Herpetología 20:3-79.

652 Burmeister H. 1861. Reise durch die La Plata-Staaten mit besonderer Rücksicht auf die Physische 653 Beschaffenheit und den Culturzustand der Argentinische Republik. Ausgefuhrt in den Jahren 1857, 654 1858, 1859 un 1860. Volume 2. Halle: HW Schmidt.

655 Camargo A, de Sá RO, Heyer WR. 2006. Phylogenetic analyses of mtDNA sequences reveal 656 three cryptic lineages in the widespread neotropical frog Leptodactylus fuscus (Schneider, 1799) 
657 (Anura, Leptodactylidae). Biological Journal of the Linnean Society 87:325-341 DOI 658 10.1111/j.1095-8312.2006.00581.x.

659 Caminer MA, Milá B, Jansen M, Fouquet A, Venega PJ, Chávez G, Lougheed SC, Ron SR. 660 2017. Systematics of the Dendropsophus leucophyllatus species complex (Anura: Hylidae): 661 Cryptic diversity and the description of two new species. PloS one 12:e0171785 DOI 662 10.1371/journal.pone.0171785.

663 Caramaschi U, Feio RN, São-Pedro VA. 2008. A new species of Leptodactylus Fitzinger (Anura, 664 Leptodactylidae) from Serra do Brigadeiro, State of Minas Gerais, Southeastern Brazil. Zootaxa 665 1861:44-54.

666 Cassini CS, Orrico VG, Dias IR, Sole M, Haddad CFB. 2013. Phenotypic variation of 667 Leptodactylus cupreus Caramaschi, São-Pedro and Feio, 2008 (Anura, Leptodactylidae). Zootaxa 668 3616:73-84.

669 Castroviejo-Fisher S, Köhler J, de La Riva I, Padial JM. 2017. A new morphologically cryptic 670 species of Phyllomedusa (Anura: Phyllomedusidae) from Amazonian forests of northern Peru 671 revealed by DNA sequences. Zootaxa 4269:245-264 DOI 10.11646/zootaxa.4269.2.4.

672 Cei JM. 1980. Amphibians of Argentina. Vol. 2. Firenze: Università degli Studi di Firenze.

673 Cochran DM. 1961. Type specimens of reptiles and amphibians in the U.S National Museum.

674 Washington: Government Printing Office Washington.

675 Cope ED. 1877. Tenth contribution to the herpetology of tropical America. Proceedings of the 676 American Philosophical Society 17:85-98.

677 Crombie RI, Heyer WR. 1983. Leptodactylus longirostris (Anura: Leptodactylidae):

678 Advertisement call, tadpole, ecological and distributional notes. Revista Brasileira de Biologia 679 43:291-296. 
680 de Carvalho CB, Freitas EBD, Faria RG, Batista RDC, Batista CDC, Coelho WA,

681 Bocchiglieri A. 2008. Natural history of Leptodactylus mystacinus and Leptodactylus fuscus

682 (Anura: Leptodactylidae) in the Cerrado of Central Brazil. Biota Neotropical 8: 105-115 DOI

$68310.1590 / \mathrm{S} 1676-06032008000300010$.

684 de Carvalho TR, Leite FSF, Pezzuti TL. 2013. A new species of Leptodactylus Fitzinger (Anura,

685 Leptodactylidae, Leptodactylinae) from montane rock fields of the Chapada Diamantina, 686 northeastern Brazil. Zootaxa 3701:349-364 DOI 10.11646/zootaxa.3701.3.5.

687 de Sá RO, Grant T, Camargo A, Heyer WR, Ponssa ML, Stanley E. 2014. Systematics of the 688 neotropical genus Leptodactylus Fitzinger, 1826 (Anura: Leptodactylidae): phylogeny, the 689 relevance of non-molecular evidence, and species accounts. South American Journal of 690 Herpetology 9(s1): S1-S100 DOI 10.2994/SAJH-D-13-00022.1

691 Dinerstein E, Olson DM, Graham DJ, Webster AL, Primm SA, Bookbinder MP, Ledec G.

692 1995. A conservation assessment of the terrestrial ecoregions of Latin America and the Caribbean.

693 Washington, DC: World Bank.

694 Duellman WE. 1970. The hylid frogs of Middle America. Vol. 1. Kansas: Monograph of the 695 Museum of Natural History.

696 Emerson SB. 1982. Frog postcranial morphology: identification of a functional complex. Copeia $6973: 603-613$.

698 Fabrezi M. 1992. El carpo de los anuros. Alytes 10:1-29.

699 Fabrezi M. 1993. The anuran tarsus. Alytes 11:47-63.

700 Fabrezi M, Alberch P. 1996. The carpal elements of anurans. Herpetologica 52:188-204.

701 Faivovich J, Nicoli L, Blotto BL, Pereyra MO, Baldo D, Barrionuevo JS, Fabrezi M, Wild 702 ER, Haddad CFB. 2014. Big, bad, and beautiful: phylogenetic relationships of the horned frogs 
703 (Anura: Ceratophryidae). South American Journal of Herpetology 9:207-228 DOI 10.2994/SAJH704 D-14-00032.1.

705 Farris JS, Albert VA, Källersjö M, Lipscomb D, Kluge AG. 1996. Parsimony jackknifing 706 outperforms neighbor-joining. Cladistics 12:99-124 DOI 10.1006/clad.1996.0008.

707 Fouquet A, Blotto BL, Maronna MM, Verdade VK, Juncá FA, de Sá R, Rodrigues MT. 2013. 708 Unexpected phylogenetic positions of the genera Rupirana and Crossodactylodes reveal insights 709 into the biogeography and reproductive evolution of leptodactylid frogs. Molecular Phylogenetics 710 and Evolution 67:4453-457 DOI 10.1016/j.ympev.2013.02.009.

711 Frost DR. 2019. Amphibian Species of the World: an Online Reference. Version 6.0. New York: 712 American $\quad$ Museum Natural History. Available at 713 http://research.amnh.org/herpetology/amphibia/index.html (accessed 16 January 2019).

714 Frost DR, Grant T, Faivovich J, Bain RH, Haas A, Haddad CFB, de Sá RO, Channing A, 715 Wilkinson M, Donnellan SC, Raxworthy CJ, Campbell JA, Blotto BL, Moler P, Drewes RC, 716 Nussbaum RA, Lynch JD, Green DM, Wheeler WC. 2006. The amphibian tree of life. Bulletin 717 of the American Museum of Natural History 33:1-291 DOI 10.1206/0003718 0090(2006)297[0001:TATOL]2.0.CO;2.

719 Funk WC, Caminer M, Ron SR. 2011. High levels of cryptic species diversity uncovered in 720 Amazonian frogs. Proceedings of the Royal Society B: Biological Sciences 279:1806-1814 DOI 721 10.1098/rspb.2011.1653.

722 Gasparri NI, Grau HR. 2009. Deforestation and fragmentation of Chaco dry forest in NW 723 Argentina (1972-2007). Forest Ecology and Management 258:913-921 DOI $724 \quad 0.1016 /$ j.foreco.2009.02.024. 
725 Gazoni T, Haddad CFB, Narimatsu H, Cabral-de-Mello DC, Lyra ML, Parise-Maltempi PP.

726 2018. More sex chromosomes than autosomes in the Amazonian frog Leptodactylus pentadactylus.

727 Chromosoma 127:269-278 DOI 10.1007/s00412-018-0663-z.

728 Giaretta AA, Costa HC. 2007. A redescription of Leptodactylus jolyi Sazima and Bokermann

729 (Anura, Leptodactylidae) and the recognition of a new closely related species. Zootaxa 1608:1-10

730 DOI 10.11646/zootaxa.1608.1.1.

731 Goloboff PA, Farris JS, Nixon KC. 2008. TNT, a free program for phylogenetic analysis.

732 Cladistics 24:774-786 DOI 10.1111/j.1096-0031.2008.00217.x.

733 Grau HR, Torres R, Gasparri NI, Blendinger PG, Marinaro S, Macchi L. 2015. Natural

734 grasslands in the Chaco. A neglected ecosystem under threat by agriculture expansion and forest-

735 oriented conservation policies. Journal of Arid Environments 123:40-46 DOI

736 10.1016/j.jaridenv.2014.12.006.

737 Hall TA. 1999. BioEdit: a user-friendly biological sequence alignment editor and analysis

738 program for Windows 95/98/NT. Nucleic acids symposium series 41:95-98.

739 Hedges SB. 1994. Molecular evidence for the origin of birds. Proceedings of the National

740 Academy of Sciences 91:2621-2624.

741 Heyer MM, Heyer WR, de Sá RO. 2003. Leptodactylus mystacinus. Catalogue of American

742 Amphibians and Reptiles 767:1-11.

743 Heyer MM, Heyer WR, de Sá RO. 2006. Leptodactylus fragilis (Brocchi): White-lipped Thin-

744 toed Frog. Catalogue of American Amphibians and Reptiles 830:1-26.

745 Heyer WR. 1969a. Studies on the Genus Leptodactylus (Amphibia, Leptodactylidae): A

746 Redefinition of the Genus Leptodactylus and a Description of a New Genus of Leptodactylid

747 Frogs. Contributions in Science 155:1-14. 
748 Heyer WR. 1969b. The adaptive ecology of the species groups of the genus Leptodactylus

749 (Amphibia, Leptodactylidae). Evolution 23:421-428.

750 Heyer WR. 1970. Studies on the frogs of the genus Leptodactylus (Amphibia: Leptodactylidae).

751 Biosystematics of the melanonotus group. Contributions in Science 191:1-48.

752 Heyer WR. 1973. Systematics of the marmoratus group of the frog genus Leptodactylus

753 (Amphibia, Leptodactylidae). Contributions in Science 251:1-50.

754 Heyer WR. 1974. Vanzolinius, a new genus proposed for Leptodactylus discodactylus (Amphibia,

755 Leptodactylidae). Proceedings of the Biological Society of Washington 87:81-90.

756 Heyer WR. 1978. Systematics of the fuscus group of the frog genus Leptodactylus (Amphibia,

757 Leptodactylidae). Natural History Museum of Los Angeles County 29:1-85.

758 Heyer WR. 1979. Systematics of the pentadactylus species group of the frog genus Leptodactylus

759 (Amphibia, Leptodactylidae). Smithsonian contribution to zoology 301:1-423.

760 Heyer WR. 1983. Clarification of the names Rana mystacea Spix, 1824, Leptodactylus 761 amazonicus Heyer, 1978 and a description of a new species, Leptodactylus spixi (Amphibia:

762 Leptodactylidae). Proceedings of the Biological Society of Washington 96:270-272.

763 Heyer WR. 1998. The relatioships of Leptodactylus diedrus (Anura, Leptodactylidae). Alytes 764 16:1-24.

765 Heyer WR, García-Lopez JM, Cardoso AJ. 1996. Advertisement call variation in the 766 Leptodactylus mystaceus species complex (Amphibia: Leptodactylidae) with a description of a 767 new sibling species. Amphibia-Reptilia 17:7-31 DOI 10.1163/156853896X00252.

768 Heyer WR, Heyer MM. 2002. Leptodactylus elenae Heyer. Catalogue of American Amphibians 769 and Reptiles 742:1-5. 
770 Heyer WR, Heyer MM, de Sá RO. 2010. Leptodactylus syphax. Catalogue of American

771 Amphibians and Reptile 868:1-9.

772 Heyer WR, Juncá FA. 2003. Leptodactylus caatingae, a new species of frog from eastern Brazil

773 (Amphibia: Anura: Leptodactylidae). Proceedings of the biological Society of Washington 774 116:317-329.

775 Heyer WR, Rand AS, da Cruz CAG, Peixoto OL, Nelson CE. 1990. Frogs of Boracéia. 776 Arquivos de Zoologia 31:231-410.

777 Heyer WR, Reid YR. 2003. Does advertisement call variation coincide with genetic variation in 778 the genetically diverse frog taxon currently known as Leptodactylus fuscus (Amphibia:

779 Leptodactylidae)? Anais da Academia Brasileira de Ciências 75:39-54 DOI 10.1590/S000178037652003000100006.

781 Heyer WR, Thompson AS. 2000. Leptodactylus rugosus. Catalogue of American Amphibians 782 and Reptiles 708:1-5.

783 Ibisch PL, Columba K, Reichle S. 2002. Plan de conservación y desarrollo sostenible para el 784 Bosque Seco Chiquitano, Cerrado y Pantanal Boliviano. La Guardia: Editorial FAN.

785 Jansen M, Bloch R, Schulze A, Pfenninger M. 2011. Integrative inventory of Bolivia's lowland 786 anurans reveals hidden diversity. Zoologica Scripta 40:567-583 DOI 10.1111/j.1463787 6409.2011.00498.x.

788 Jansen M, Masurowa A, O'Hara RB. 2016. Temporal variation, duty cycle, and absolute calling 789 effort during sustained calling of Leptodactylus mystacinus (Anura: Leptodactylidae). 790 Salamandra 52:328-336.

791 Katoh K, Toh H. 2008. Recent developments in the MAFFT multiple sequence alignment 792 program. Briefings in bioinformatics 9:276-285 DOI 10.1093/bib/bbn013. 
793 Kellogg R. 1932. Mexican tailless amphibians in the United States National Museum. Bulletin of 794 the United States National Museum 160:1-224.

795 Kocher TD, Thomas WK, Meyer A Edwards SV, Pääbo S, Villablanca FX, Wilson AC. 1989. 796 Dynamics of mitochondrial DNA evolution in animals: amplification and sequencing with 797 conserved primers. Proceedings of the National Academy of Sciences 86:6196-6200 DOI $798 \quad 10.1073 /$ pnas.86.16.6196.

799 Köhler J. 2000. Amphibian diversity in Bolivia: a study with special reference to montane forest 800 regions. Bonner zoologische Monographien 48:1-243.

801 Köhler J, Jansen M, Rodríguez A, Kok PJR, Toledo LF, Emmrich M, Glaw F, Haddad CFB, 802 Rödel MO, Vences M. 2017. The use of bioacoustics in anuran taxonomy: Theory, terminology, 803 methods and recommendations for best practice. Zootaxa 4251:1-124 DOI 804 10.11646/zootaxa.4251.1.1.

805 Kwet A, Di-Bernardo M, Garcia PC. 2001. The taxonomic status of Leptodactylus geminus 806 Barrio, 1973. Journal of Herpetology 35:56-62 DOI 10.2307/1566023.

807 Lanfear R, Calcott B, Ho SYW, Guindon S. 2012. PartitionFinder: combined selection of 808 partitioning schemes and substitution models for phylogenetic analyses. Molecular Biology and 809 Evolution 29:1695-1701. DOI 10.1093/molbev/mss020.

810 Langone JA. 1995. Ranas y sapos del Uruguay (Reconocimiento y aspectos biológicos). Museo 811 Dámaso Antonio Larrañaga, Serie de Divulgación 5:1-123.

812 Langone JA, de Sá RO. 2005. Redescripción de la morfología larval externa de dos especies del 813 grupo de Leptodactylus fuscus (Anura, Leptodactylidae). Phyllomedusa 4:49-59.

814 López-González C. 2004. Ecological zoogeography of the bats of Paraguay. Journal of 815 Biogeography 31:33-45 DOI 10.1111/j.1365-2699.2004.00940.x. 
816 Lynch JD. 1971. Evolutionary relationships, osteology, and zoogeography of leptodactyloid

817 frogs. In: Miscellaneous Publication, Museum of Natural History. Vol. 53. Lawrence, Kansas:

818 University of Kansas, 1-238.

819 Maldonado P, Hohne E. 2006. Atlas del Gran Chaco Americano. Buenos Aires: Agencia 820 Alemana de Cooperación Técnica.

821 Maxson LR, Heyer WR. 1988. Molecular systematics of the frog genus Leptodactylus 822 (Amphibia: Leptodactylidae). Fieldiana 41:1-13.

823 Miller MA, Pfeiffer W, Schwartz T. 2010. Creating the CIPRES Science Gateway for inference 824 of large phylogenetic trees. Gateway Computing Environments Workshop DOI 825 10.1109/GCE.2010.5676129.

826 Nori J, Torres R, Lescano JN, Cordier JM, Periago ME, Baldo D. 2016. Protected areas and 827 spatial conservation priorities for endemic vertebrates of the Gran Chaco, one of the most 828 threatened ecoregions of the world. Diversity and Distributions 22:1212-1219 DOI 829 10.1111/ddi.12497.

830 Oliveira Filho JCD, Giaretta AA. 2008. Reproductive behavior of Leptodactylus mystacinus 831 (Anura, Leptodactylidae) with notes on courtship call of other Leptodactylus species. Iheringia 832 98:508-515 DOI 10.1590/S0073-47212008000400015.

833 Olson DM, Dinerstein E, Wikramanayake ED, Burgess ND, Powell GV, Underwood EC, et 834 al. 2001. Terrestrial Ecoregions of the World: A New Map of Life on Earth: A new global map of 835 terrestrial ecoregions provides an innovative tool for conserving biodiversity. BioScience 51:933836938.

837 Palumbi SR, Martin A, Romano S, McMillan WO, Stice L, Grabawski G. 1991. The Simple 838 Fool's Guide to PCR. Version 2.0. Honolulu: University of Hawaii. 
839 Ponssa ML. 2006. On the osteology of a distinctive species of the genus Leptodactylus:

840 Leptodactylus laticeps (Boulenger, 1917) (Anura; Leptodactylidae). Zootaxa 1188:23-36 DOI

841 10.11646/zootaxa.1188.1.2.

842 Ponssa ML. 2008. Cladistic analysis and osteological descriptions of the frog species in the 843 Leptodactylus fuscus species group (Anura, Leptodactylidae). Journal of Zoological Systematics 844 and Evolutionary Research 46:249-266 DOI 10.1111/j.1439-0469.2008.00460.x.

845 Ponssa ML, Barrionuevo JS. 2012. Sexual dimorphism in Leptodactylus latinasus (Anura, 846 Leptodactylidae): nasal capsule anatomy, morphometric characters and performance associated 847 with burrowing behavior. Acta Zoologica 93:57-67 DOI 10.1111/j.1463-6395.2010.00479.x.

848 Rambaut A, Drummond AJ. 2007. Tracer v. 1.4. Available at http://beast.bio.ed.ac.uk/Tracer.

849 Ronquist F, Huelsenbeck JP. 2003. MrBayes 3: Bayesian phylogenetic inference under mixed 850 models. Bioinformatics 19:1572-1574 DOI 10.1093/bioinformatics/btg180.

851 Sabaj MH. 2016. Standard symbolic codes for institutional resource collections in herpetology 852 and ichthyology: an Online Reference. Version 6.5. American Society of Ichthyologists and 853 Herpetologists. Available at http://www.asih.org (accessed 31 Jan 2019).

854 Sazima I, Bokermann WCA. 1978. Cinco novas espécies de Leptodactylus do centro e sudeste 855 brasileiro (Amphibia, Anura, Leptodactylidae). Revista Brasileira de Biologia 38:899-912.

856 Silva APZ, Garcia PC, Martins VG, Bacci M, Kasahara S. 2004. Chromosomal and molecular 857 analyses of Leptodactylus gracilis gracilis, L. gracilis delattini, and L. plaumanni (Anura, 858 Leptodactylidae): taxonomic implications. Amphibia-Reptilia 25:185-196 DOI $85910.1163 / 1568538041231193$.

860 Silva APZ, Haddad CFB, Galassi GG, Kasahara S. 2006. Multiple nucleolus organizer regions 861 in Leptodactylus mystacinus (Amphibia, Anura) and comments on its systematic position in the 
862 L. fuscus group based on cytogenetic and molecular analyses. Genetica 127:35-44 DOI 863 10.1007/s10709-005-2450-z.

864 Short LL. 1975. A zoogeographic analysis of the South American Chaco avifauna. Bulletin of the 865 American Museum of Natural History 154:163-352.

866 Swofford DL. 2000. PAUP*: Phylogenetic Analysis Using Parsimony (*and Other Methods).

867 Sunderland: Sinauer Associates.

868 Taylor WR, Van Dyke GC. 1985. Revised procedures for staining and clearing small fishes and 869 other vertebrates for bone and cartilage study. Cybium 9:107-119.

870 The Nature Conservancy. 2005. Evaluación ecoregional del Gran Chaco Americano. Buenos

871 Aires: Fundación Vida Silvestre-Wildlife Conservation Society-Bolivia.

872 Trewavas E. 1933. The hyoid and larynx of Anura. Philosophical Transactions of the Royal 873 Society of London (Series B) 222:401-527.

874 Trueb L. 1973. Bones, frogs and evolution. In: Vial JL, ed. Evolutionary biology of the 875 Anurans: contemporary research on major problems. Columbia: University of Missouri Press, $876 \quad 65-132$.

877 Vaidya G, Lohman DJ, Meier R. 2011. SequenceMatrix: concatenation software for the fast 878 assembly of multi-gene datasets with character set and codon information. Cladistics 27:171-180 879 DOI 10.1111/j.1096-0031.2010.00329.x.

880 Vences M, Chiari Y, Teschke M, Randrianiaina RD, Raharivololoniaina L, Bora P, Vieites

881 DR, Glaw F. 2008. Which frogs are out there? A preliminary evaluation of survey techniques and 882 identification reliability of Malagasy amphibians. In: Andreone F, ed. A Conservation Strategy for 883 the Amphibians of Madagascar. Torino: Monografie del Museo Regionale di Scienze Naturali, $884233-253$. 
885 Vences M, Thomas M, Meijen AVD, Chiari Y, Vieites DR. 2005. Comparative performance

886 of the 16S rRNA gene in DNA barcoding of amphibians. Frontiers in Zoology 2:5 DOI

$887 \quad 10.1186 / 1742-9994-2-5$.

888 Vences M, Wake DB. 2007. Speciation, species boundaries and phylogeography of amphibians.

889 Amphibian biology 7:2613-2671.

890 Wiens JJ, Fetzner Jr JW, Parkinson CL, Reeder TW. 2005. Hylid frog phylogeny and 891 sampling strategies for speciose clades. Systematic Biology 54:778-807 DOI $89210.1080 / 10635150500234625$.

893 Wynn A, Heyer WR. 2001. Do geographically widespread species of tropical amphibians exist? 894 An estimate of genetic relatedness within the neotropical frog Leptodactylus fuscus Schneider 895 1799) (Anura Leptodactylidae). Tropical Zoology 14:255-285 DOI

$89610.1080 / 03946975.2001 .10531157$. 


\section{Figure 1}

Consensus tree from Maximum Parsimony (MP) analysis.

(A) Phylogenetic relationships among species in the genus Leptodactylus. Branch colors refer to the species groups within Leptodactylus: green $=L$. pentadactylus species group, blue $=$ $L$. melanonotus species group, orange $=L$. latrans species group, red $=L$. fuscus species group. (B) Phylogenetic relationships of Leptodactylus apepyta sp. nov. and Leptodactylus mystacinus, and related species. Bootstrap and Jackknife supports higher to $50 \%$ are showing above and below branches respectively. Photos: Diego Baldo. 
A

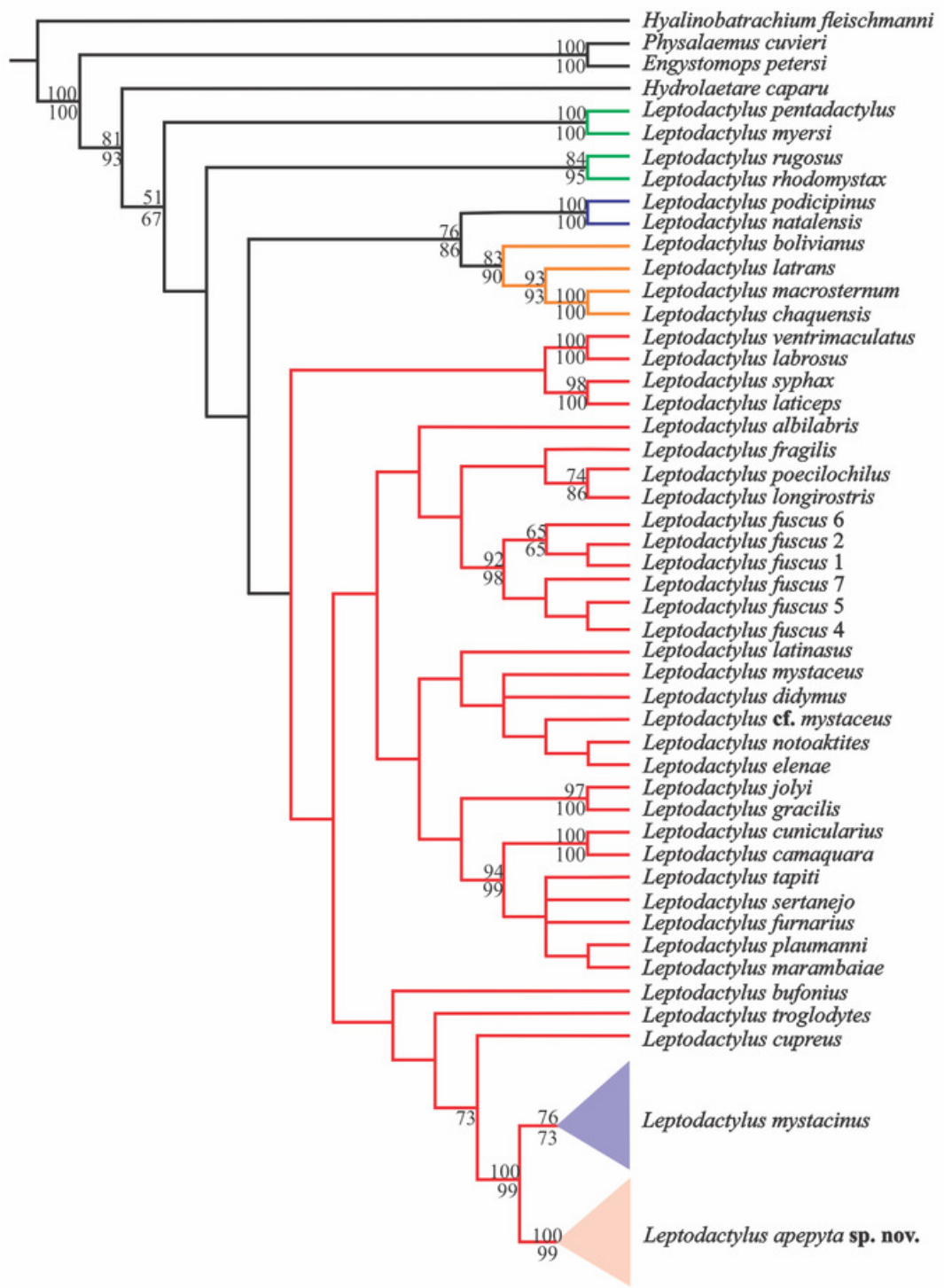

B

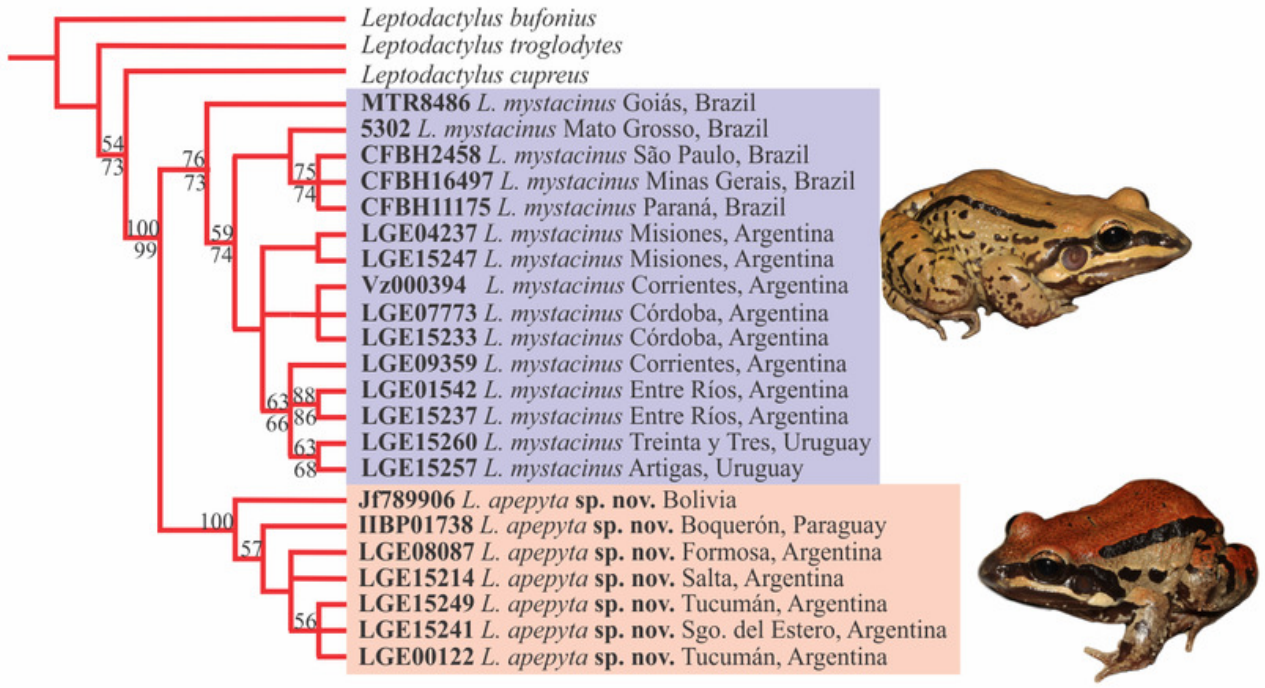


Figure 2

Holotype of Leptodactylus apepyta sp. nov.

(A) Dorsal, (B) ventral, (C) lateral views of the head; (D) ventral view of the right hand, and

(E) ventral view of the right foot of the holotype (LGE 8114). Scale bar $=10 \mathrm{~mm}$. SVL 52.3

mm. Photo: Rosio Schneider. 
$\mathbf{A}$

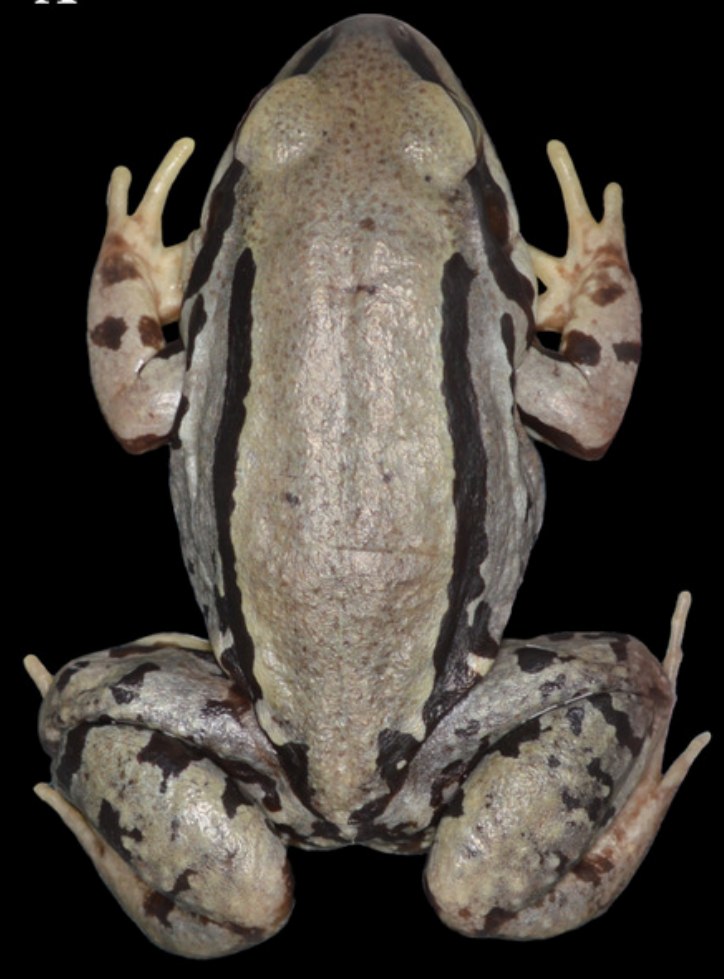

B

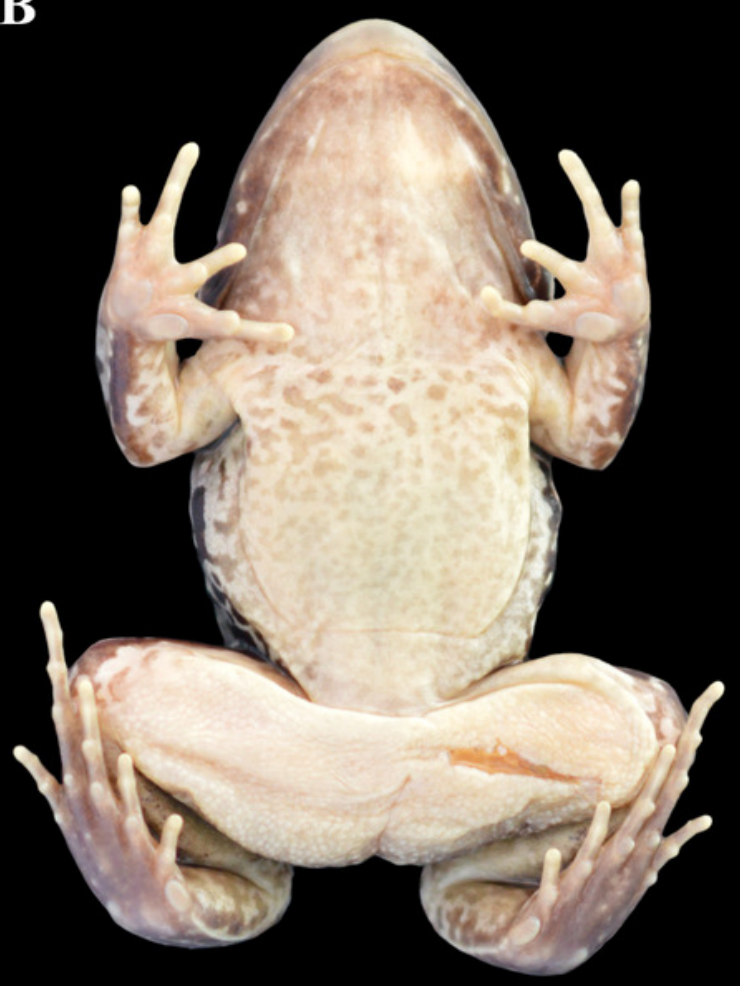

C

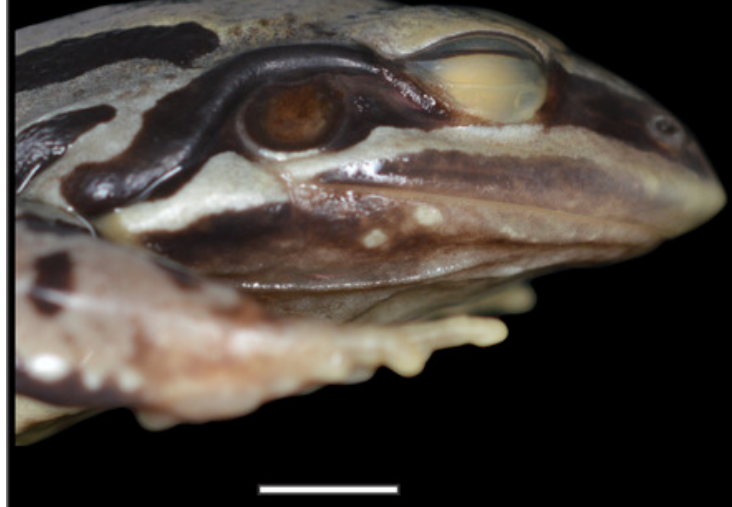

D

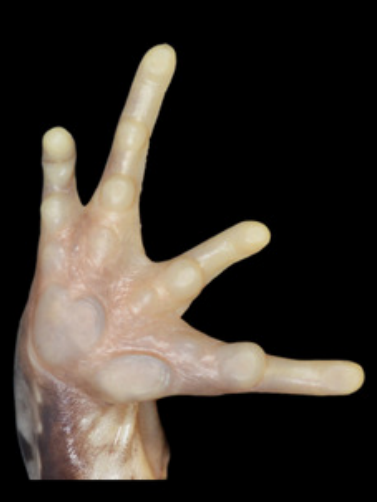

$\mathbf{E}$

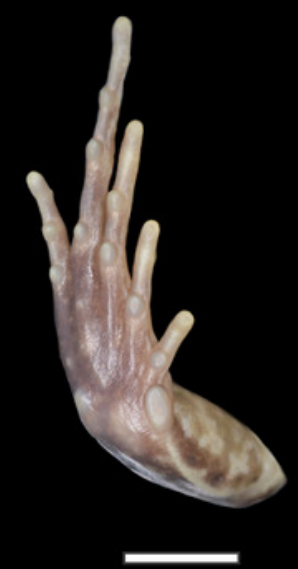


Figure 3

Skeleton of Leptodactylus apepyta sp. nov.

(A) Dorsal and (B) ventral views of skull (LGE 15214), (C) hyoid (FML 3661), (D) vertebral column in dorsal view (LGE 15214), (E) epicoracoid cartilages (FML 3661), (F) palmar view of hand, (G) plantar view of foot (LGE 15214). Scale bar $=2 \mathrm{~mm}$. Photo: Rosio Schneider. 

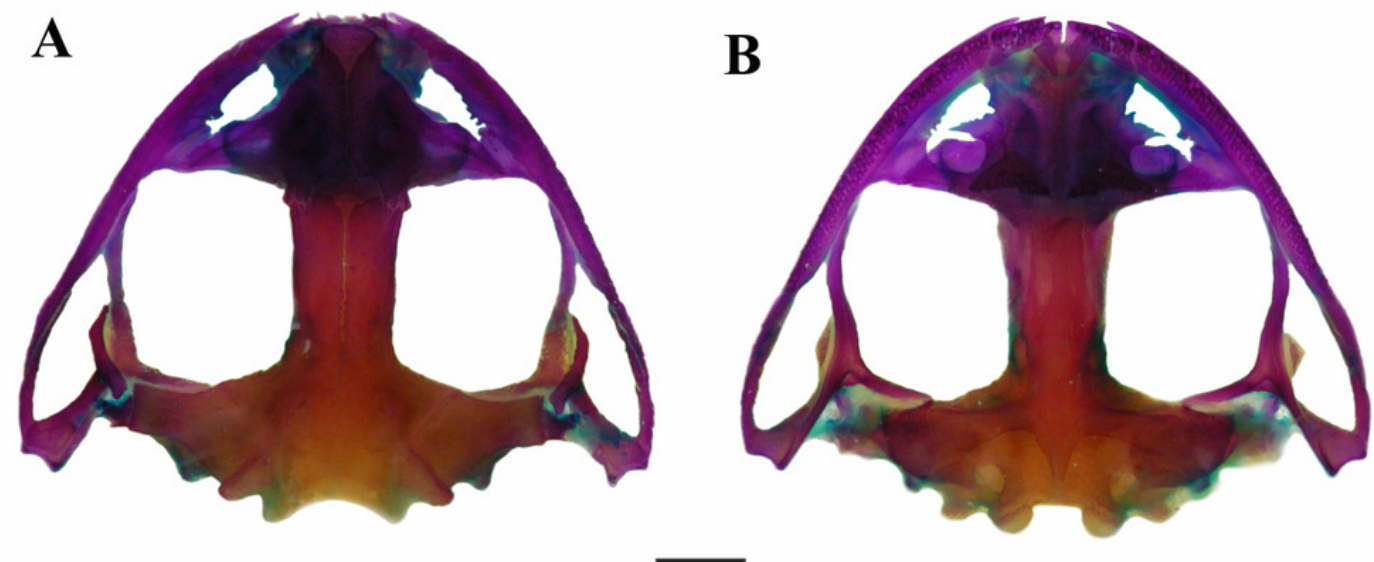

C

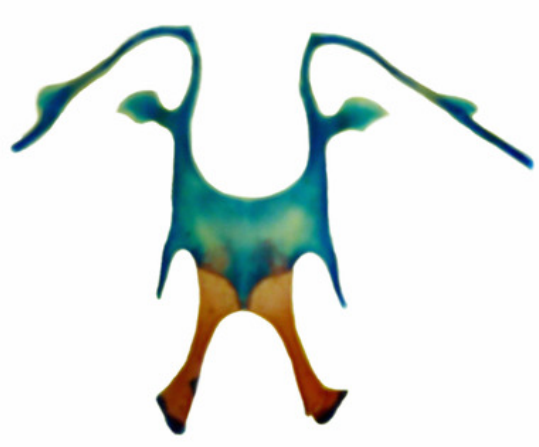

D

$\mathbf{E}$

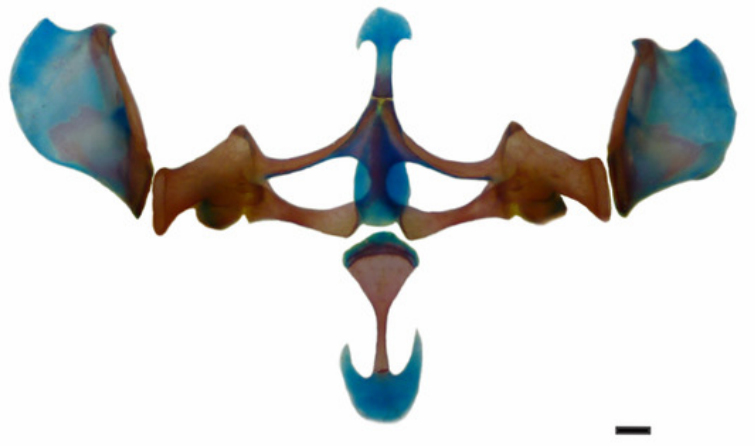

F

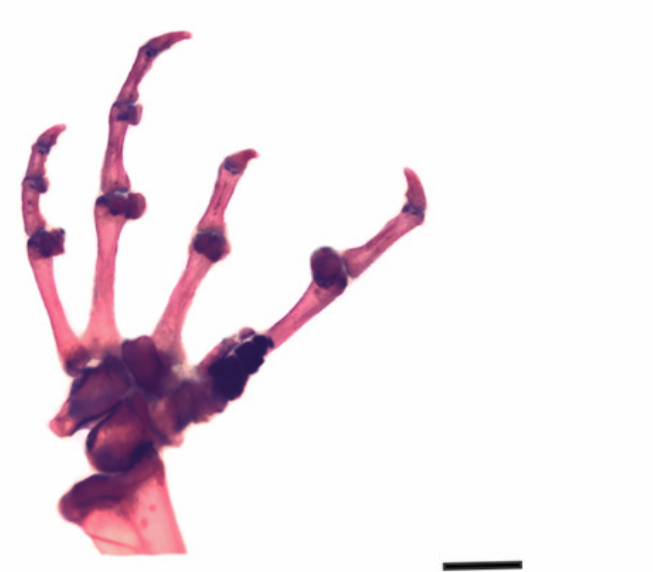

G
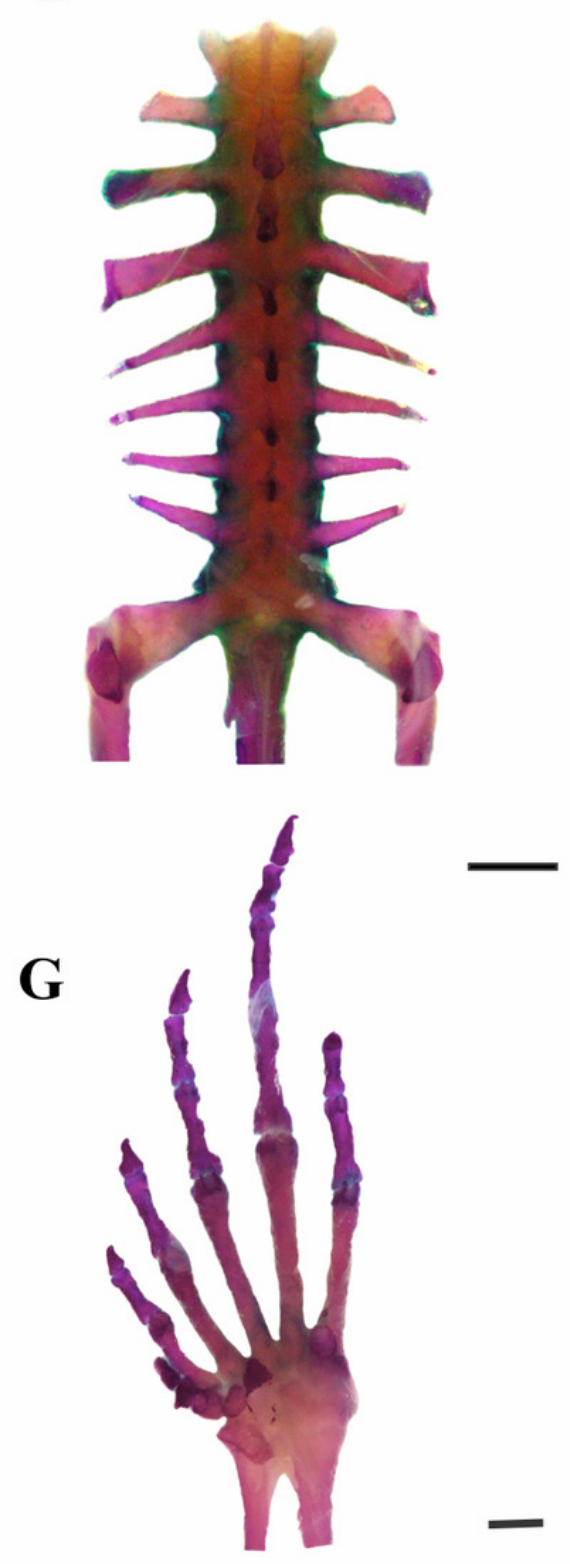
Figure 4

Advertisement calls.

(A) Oscillogram and (B) spectrogram of Leptodactylus apepyta sp. nov. from Las Lomitas, Formosa province, Argentina (LGE 8085); (C) Oscillogram and (D) spectrogram of Leptodactylus mystacinus from Rosario, Santa Fé province, Argentina (unvouchered specimen). Ms= miliseconds, $\mathrm{Hz}=$ Hertz.

A
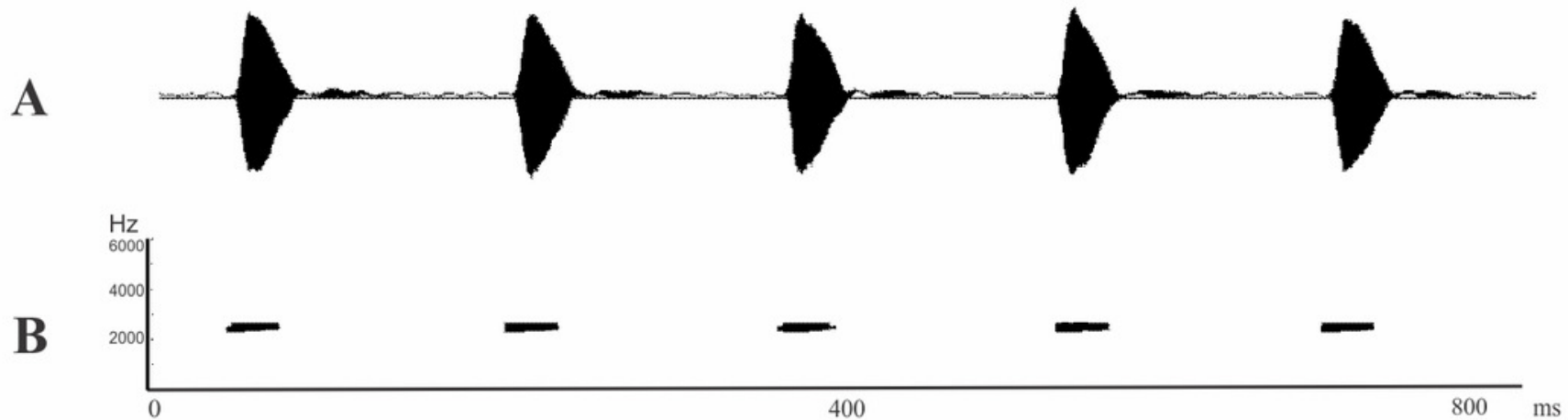

C
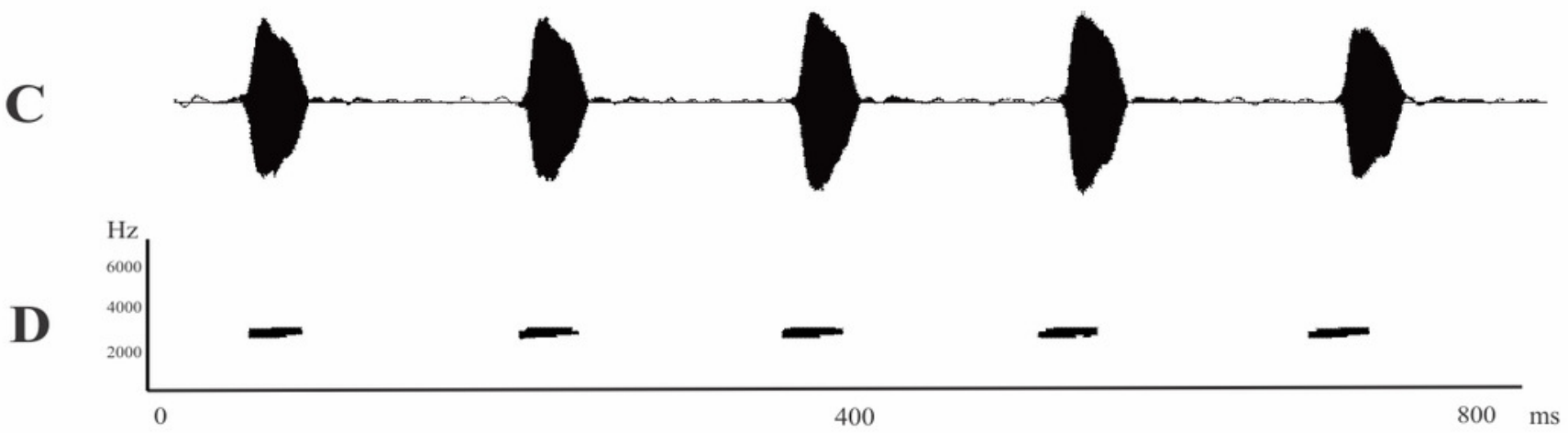


\section{Figure 5}

Leptodactylus apepyta sp. nov.

(A) Dorsolateral view of the holotype (LGE 8114) in life; (B) male vocalizing from a log (LGE 15240). Photo: Diego Baldo.

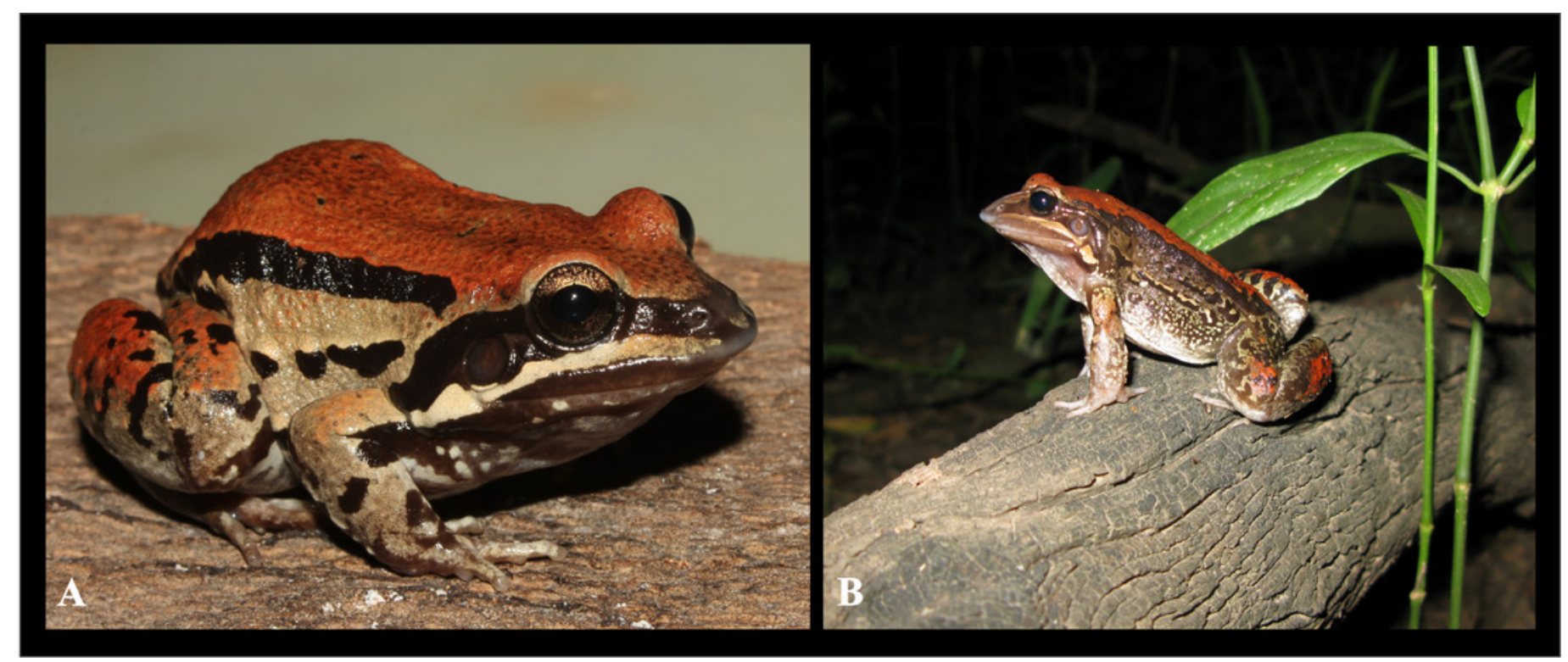


Figure 6

Intraspecific variation observed in Leptodactylus apepyta sp. nov.
(A) LGE 8085,
(B) LGE 8087,
(C) LGE15241, (D) LGE 8114,
(E) LGE 8181, (F) LGE 9399, (G)

LGE 15240, (H) LGE 15232, (I) IIBP-H 729, (J) LGE 8113, (K) LGE 8384, (L) LGE 8086. See S2 Appendix for locality data. Photos: Diego Baldo.

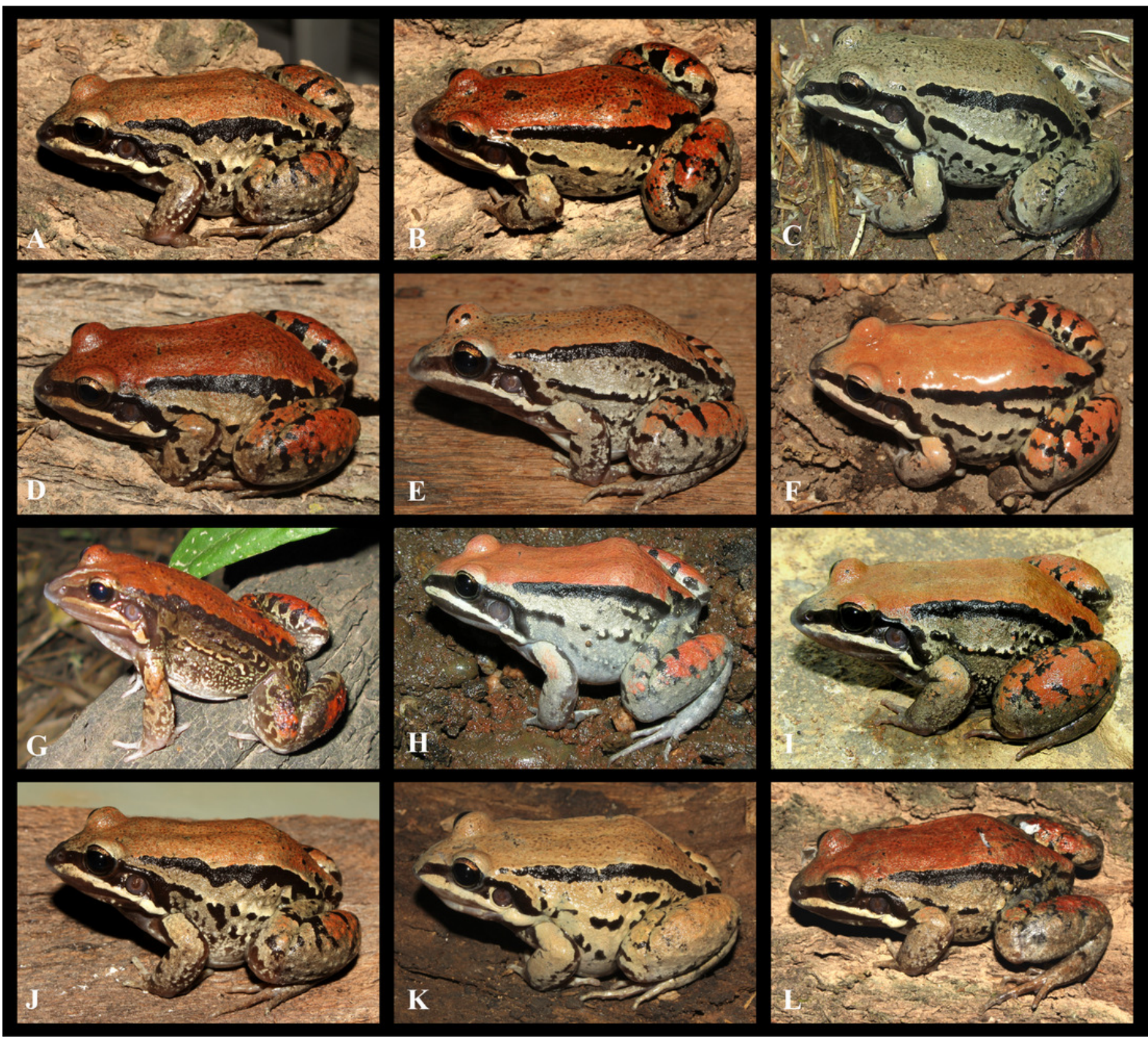


Figure 7

Intraspecific variation observed in Leptodactylus mystacinus.
(A) LGE 20956,
(B) LGE 7773,
(C) LGE 15206, (D) LGE 7606,
(E) LGE 9343, (F) LGE 15254, (G)

LGE 15264, (H) LGE 7890, (I) IIBP-H 1086. See S2 Appendix for locality data. Photos: Diego

Baldo.

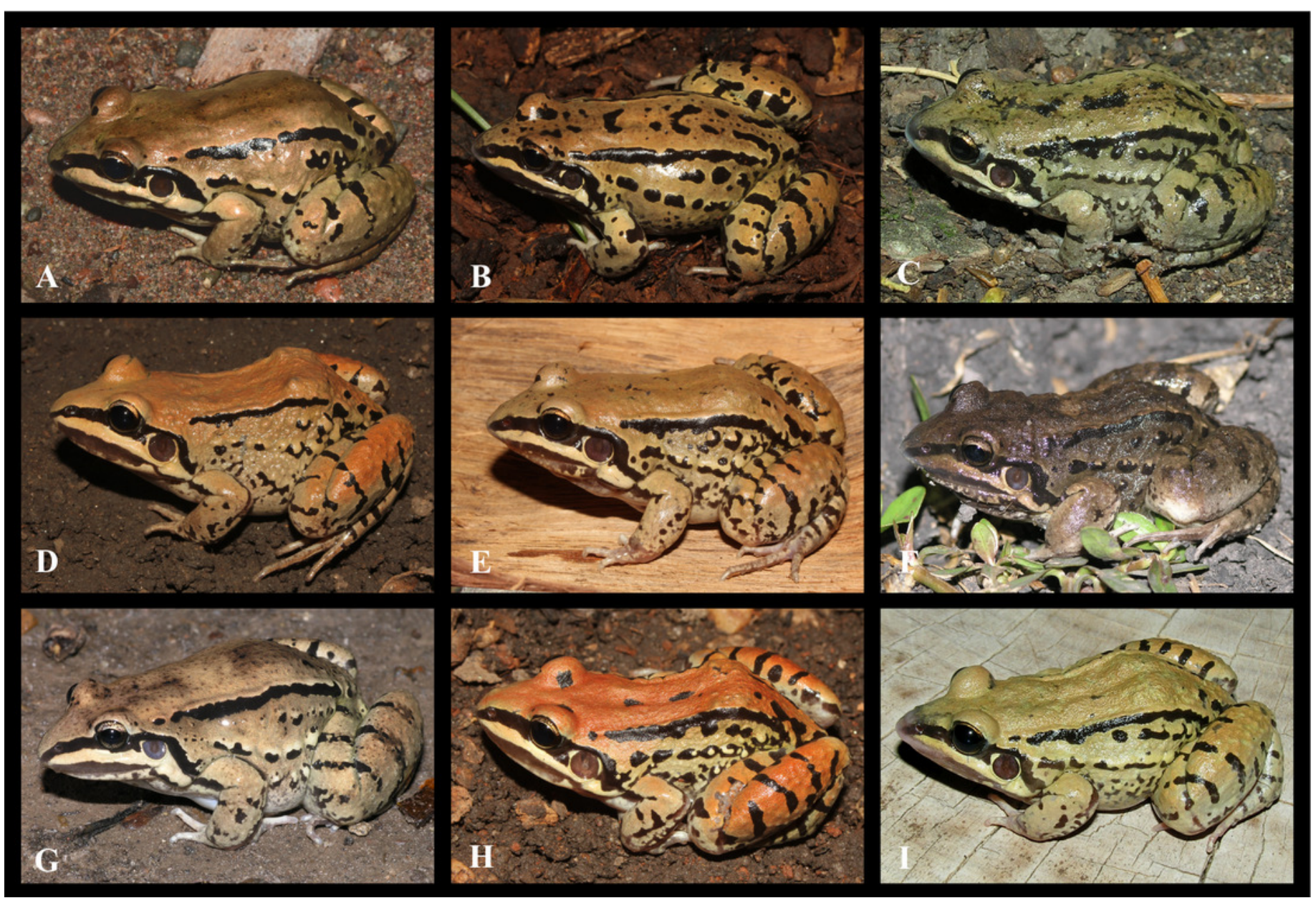




\section{Figure 8}

Geographic distribution of Leptodactylus apepyta sp. nov. and L. mystacinus.

Localities based on examined specimens (Appendix II). Black circles: L. apepyta sp. nov., black star indicates their type locality (Las Lomitas, Formosa province, Argentina); white circles: L. mystacinus, white star indicates their type locality (Rosario, Santa Fe province, Argentina). Red borders on circles show sequences used in molecular analysis. Area enclosed in black denotes the limits of the South American Gran Chaco. South American ecoregions modified from Olson et al. (2001). 


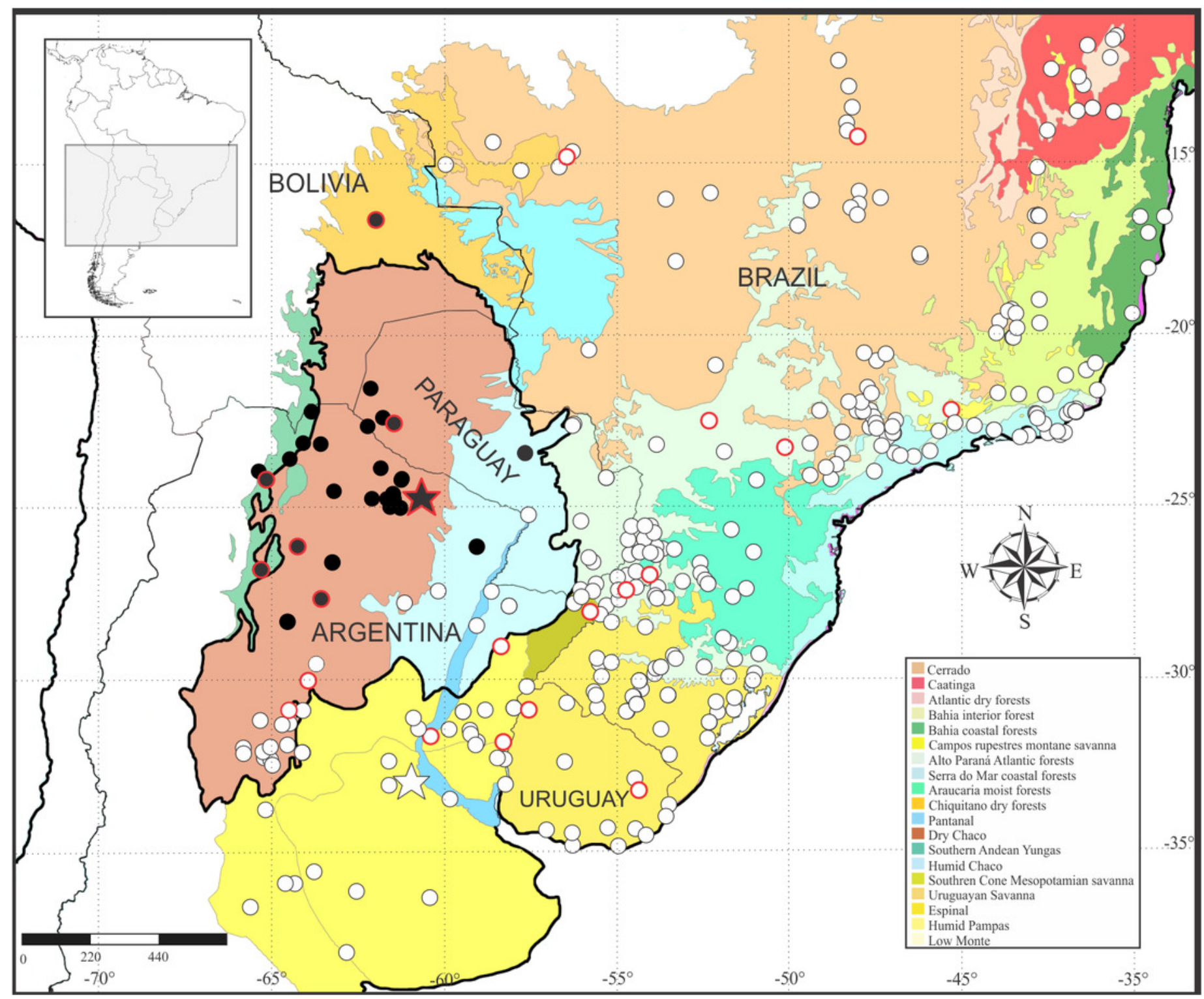




\section{Table 1 (on next page)}

Morphometric variables (in $\mathrm{mm}$ ) of adult males and females of Leptodactylus apepyta sp. nov. and L. mystacinus.

$\mathrm{N}=$ number of specimens measured. Ranges (Mean $\pm \mathrm{SD}$ ). 


\begin{tabular}{|c|c|c|c|c|}
\hline \multirow[t]{2}{*}{ Measurements } & \multicolumn{2}{|c|}{ Leptodactylus apepyta $\mathbf{s p . ~ n o v . ~}$} & \multicolumn{2}{|c|}{ Leptodactylus mystacinus } \\
\hline & Males $(\mathrm{N}=43)$ & Females $(\mathrm{N}=6)$ & Males $(\mathrm{N}=584)$ & Females $(\mathrm{N}=150)$ \\
\hline \multirow{2}{*}{$\begin{array}{l}\text { Snout-vent } \\
\text { length }\end{array}$} & $46.80-61.41$ & $51.67-66.21$ & $45.1-60.87$ & $45.47-66.10$ \\
\hline & $(53.77 \pm 5.07)$ & $(59.17 \pm 5.64)$ & $(51.57 \pm 3.18)$ & $(56.25 \pm 4.09)$ \\
\hline \multirow[t]{2}{*}{ Head length } & $14.96-21.63$ & $18.13-21.55$ & $14.96-24.71$ & $14.79-27.12$ \\
\hline & $(18.26 \pm 1.48)$ & $(20.31 \pm 1.55)$ & $(19.44 \pm 1.64)$ & $(20.61 \pm 2.2)$ \\
\hline \multirow[t]{2}{*}{ Head width } & $15.25-23.46$ & $19.97-24.3$ & $14.22-22.1$ & $16.34-23.18$ \\
\hline & $(20.13 \pm 1.89)$ & $(22.06 \pm 1.72)$ & $(18.06 \pm 1.21)$ & $(19.82 \pm 1.5)$ \\
\hline \multirow[t]{2}{*}{ Eye diameter } & $3.67-7.11$ & $5.25-6.73$ & $2.82-7.37$ & $4.04-7.17$ \\
\hline & $(5.6 \pm 0.72)$ & $(5.81 \pm 0.61)$ & $(5.42 \pm 0.63)$ & $(5.7 \pm 0.56)$ \\
\hline \multirow{2}{*}{$\begin{array}{l}\text { Tympanum } \\
\text { diameter }\end{array}$} & $3.08-4.22$ & $3.84-4.32$ & $3.14-5.87$ & $3.65-5.99$ \\
\hline & $(3.74 \pm 0.46)$ & $(4.15 \pm 0.17)$ & $(4.41 \pm 0.53)$ & $(4.76 \pm 0.57)$ \\
\hline \multirow{2}{*}{$\begin{array}{l}\text { Eye-nostril } \\
\text { distance }\end{array}$} & $3.64-5.84$ & $4.12-5.5)$ & $1.95-5.87$ & $3.74-6.07$ \\
\hline & $(4.68 \pm 0.42)$ & $(4.85 \pm 0.56)$ & $(4.69 \pm 0.47)$ & $(5.19 \pm 0.42)$ \\
\hline \multirow{2}{*}{$\begin{array}{l}\text { Internarial } \\
\text { distance }\end{array}$} & $2.9-4.64$ & $6.65-4.44$ & $2.37-4.89$ & $2.64-5.27$ \\
\hline & $(3.79 \pm 0.46)$ & $(3.99 \pm 0.31)$ & $(3.7 \pm 0.4)$ & $(4.06 \pm 0.46)$ \\
\hline \multirow{2}{*}{$\begin{array}{l}\text { Interorbital } \\
\text { distance }\end{array}$} & $2.79-4.93$ & $3.17-5.32$ & $2.27-5$ & $1.79-5.29$ \\
\hline & $(3.75 \pm 0.57)$ & $(4.25 \pm 0.91)$ & $(3.56 \pm 0.43)$ & $(3.82 \pm 0.97)$ \\
\hline \multirow{2}{*}{$\begin{array}{l}\text { Forearm } \\
\text { length }\end{array}$} & $6.97-12.45$ & $9.21-14.31$ & $6.41-13.31$ & $7.52-14.55$ \\
\hline & $(9.62 \pm 1.05)$ & $(11.21 \pm 1.73)$ & $(9.59 \pm 1.09)$ & $(10.35 \pm 1.72)$ \\
\hline \multirow[t]{2}{*}{ Hand length } & $9.8-14.2$ & $12.04-13.37$ & $8.92-12.3$ & $11-15.2$ \\
\hline & $(12.44 \pm 1.06)$ & $(12.82 \pm 0.65)$ & $(12.05 \pm 1.26)$ & $(12.97 \pm 1.44)$ \\
\hline \multirow[t]{2}{*}{ Thigh length } & $15.76-25.76$ & $21.29-26.94$ & $11.22-27$ & $14.66-28.02$ \\
\hline & $(22.42 \pm 2.45)$ & $(23.56 \pm 2.27)$ & $(21.59 \pm 2.58)$ & $(23.21 \pm 5.7)$ \\
\hline \multirow[t]{2}{*}{ Tibia length } & $17.21-25.47$ & $22.34-22.57$ & $11.87-27.96$ & $19.61-30.08$ \\
\hline & $(22.16 \pm 1.88)$ & $(24.50 \pm 1.86)$ & $(22.38 \pm 1.81)$ & $(24.52 \pm 3.33)$ \\
\hline \multirow[t]{2}{*}{ Tarsus length } & $9.79-15.43$ & $11.75-14.64$ & $9.77-24.32$ & $10.6-21.72$ \\
\hline & $(12.75 \pm 1.32)$ & $(13.5 \pm 1.08)$ & $(12.44 \pm 1.47)$ & $(13.62 \pm 1.76)$ \\
\hline \multirow[t]{2}{*}{ Foot length } & $19.24-25.22$ & $22.29-26.03$ & $11.08-27.64$ & $13.26-28.57$ \\
\hline & $(22.27 \pm 1.56)$ & $(24.27 \pm 1.45)$ & $(22.86 \pm 2.48)$ & $(24.44 \pm 2.77)$ \\
\hline
\end{tabular}




\section{Table 2 (on next page)}

Advertisement call variables of Leptodactylus apepyta sp. nov. and L. mystacinus.

$\mathrm{N}=$ number of recorded individuals (number of analyzed calls). Ranges (Mean \pm SD). 


\begin{tabular}{lcc}
\hline Bioacoustics variables & Leptodactylus apepyta sp. nov. & Leptodactylus mystacinus \\
& $\mathrm{N}=5(241)$ & $\mathrm{N}=41(1250)$ \\
\hline Call duration (ms) & $30-68$ & $27-66$ \\
& $(42.2 \pm 0.82)$ & $(43.62 \pm 0.74)$ \\
\hline Intercall interval (ms) & $88-204$ & $84-221$ \\
& $(132.5 \pm 2.91)$ & $(124.6 \pm 2.31)$ \\
\hline Dominant frequency & $2155-2457$ & $1960-2874$ \\
(Hz) & $(2266.04 \pm 80.41)$ & $(2368.88 \pm 195.05)$ \\
\hline Calls/second & $3.86-7.69$ & $3.94-8.4$ \\
& $(5.92 \pm 1.04)$ & $(6.08 \pm 0.91)$ \\
\hline
\end{tabular}

1 